7.
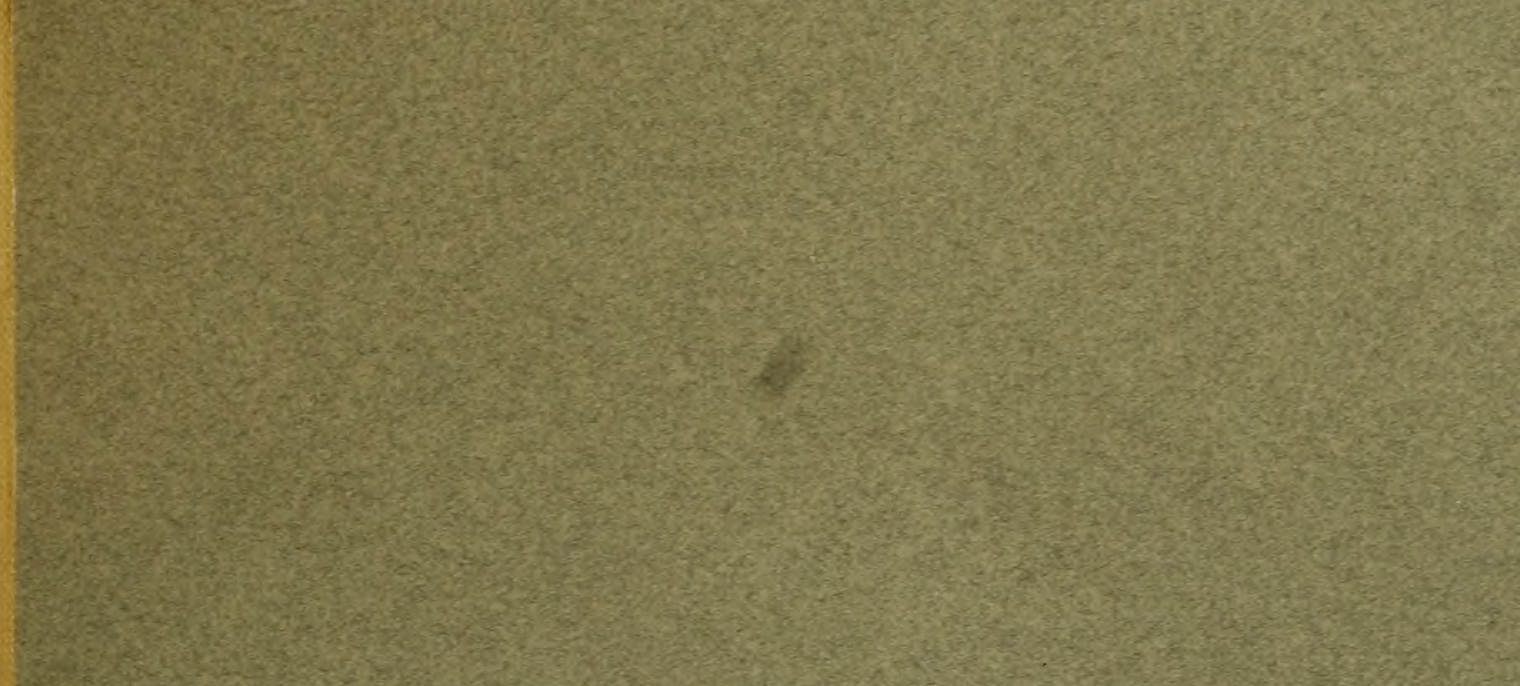

(1)

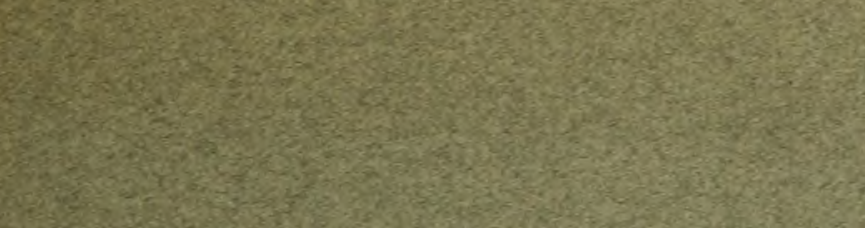

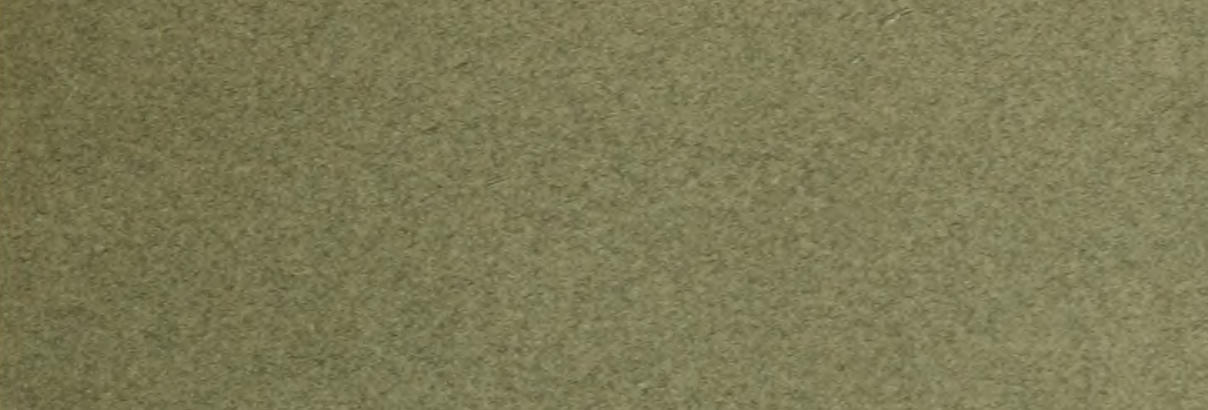

W.t.

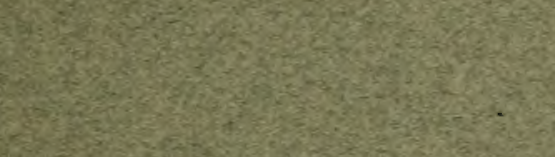

(5)

$\sin 2 \sin 20$

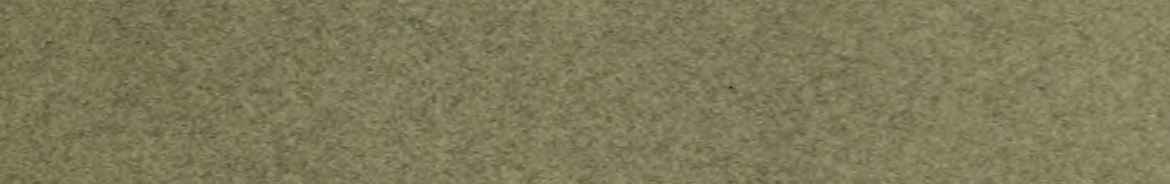

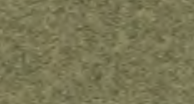

15.

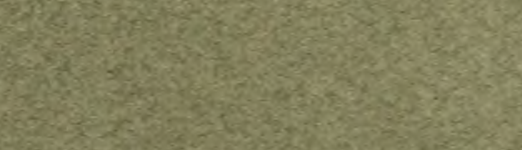
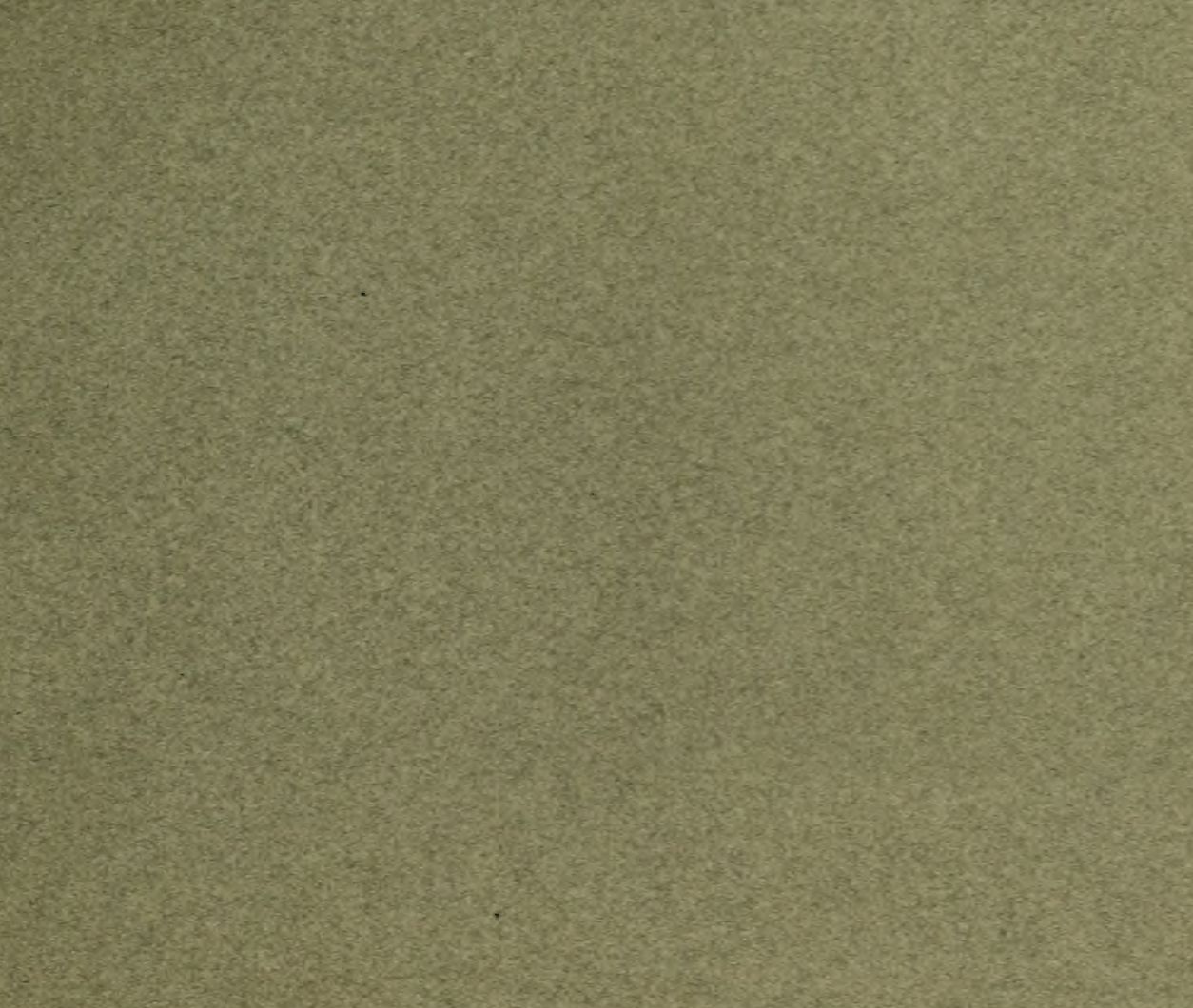

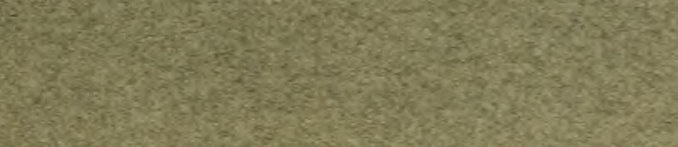

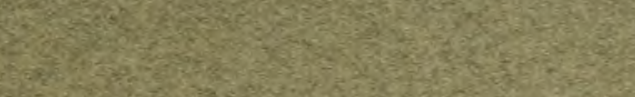

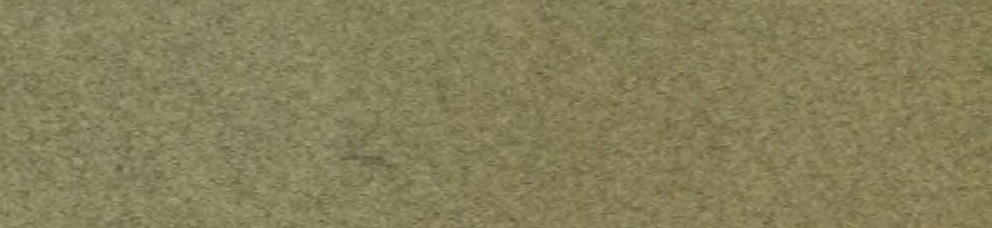
Notis

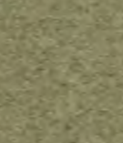




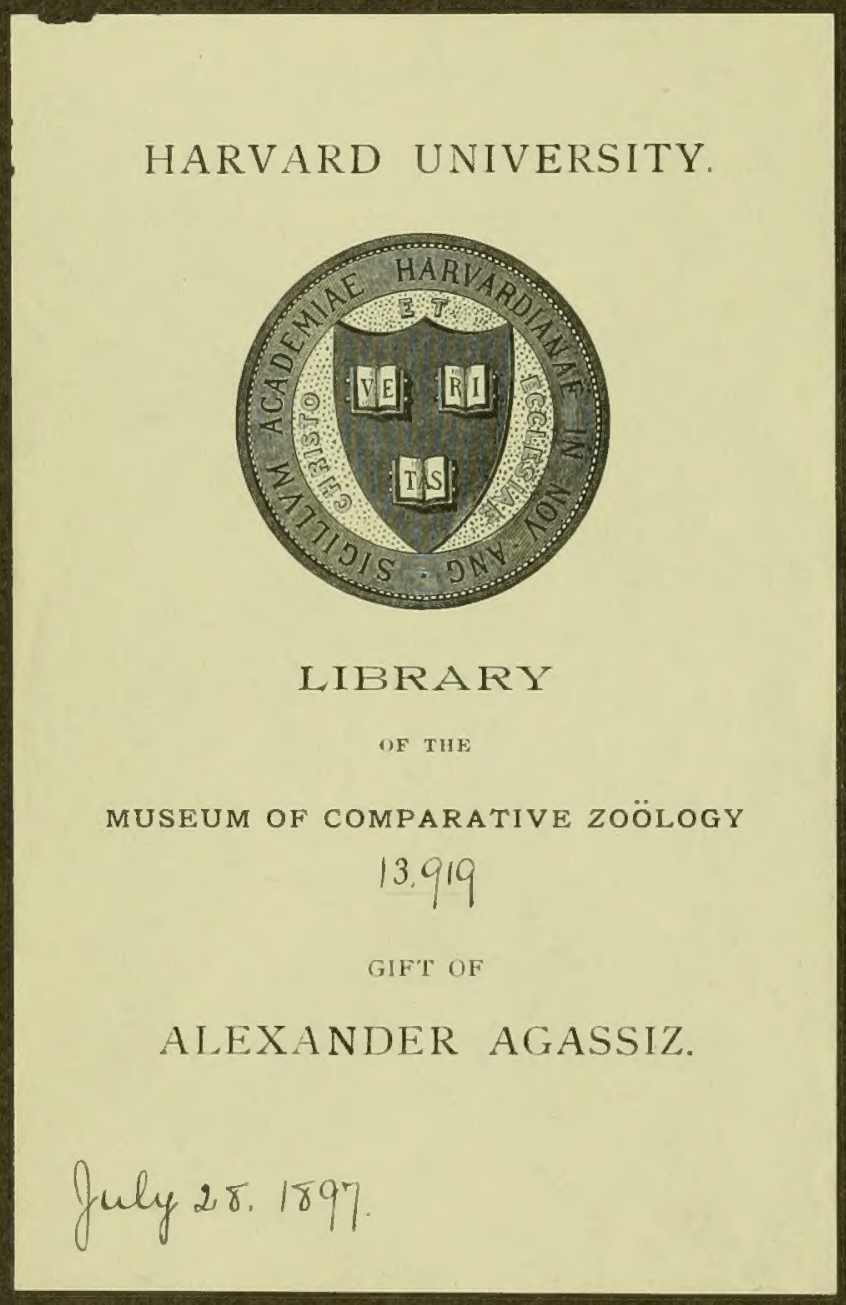


Q UEENSLA ND.

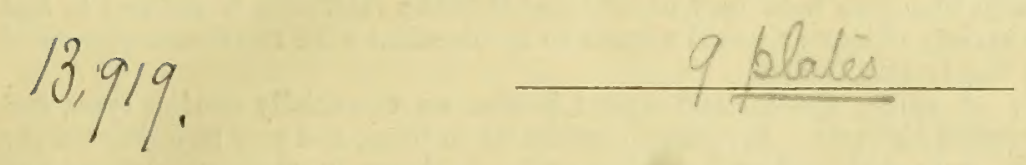

\section{OYSTERS AND OYSTER FISHERIES OF QULENSLAND.}

Presented to both Houses of Parliament by Command.

Department of Fisheries,

Brisbane, 30th June, 1891.

SIR,-I have the honour to submit to you a Report embodying the results of my observations and investigations concerning the Oysters and Oyster Fisheries of Queensland conducted within the past two years. To this is appended a return indicating the status up to date of the output of this fishery, and the number and extent of the areas leased, as supplied to me by tho district inspectors. Trusting that the data and suggestions contained in this report may conduce towards an extended and yet more profitable development of the oyster industry of this Colony.

I have, \&c.,

W. SAVILLE-KENT, F.L.S., F.Z.S., \&c.,

Commissioner of Fisheries, Queensland.

To the Honourable the Treasurer.

\section{INTRODUCTORY.}

The Oyster Fisheries of Queensland occupy the third position upon the list of the leading fisheries industries of the Colony with relation to their annual export value. That of pearlshell takes the lead with an average yearly export value of $£ 70,000$. The bêche-de-mer yields in a like manner an average of $£ 23,000$, while the oyster fisheries for the past ten yeai's have not exceeded an average of $£ 8,000$. The exceptionally high figure of $£ 13,068$ was, however, obtained in the year 1889 , and when, owing to disastrous floods which temporarily devastated extensive areas of the oyster grounds of Now South Wales, and in a less degree those of this Colony, the prices realised for the oysters exported was enormously enhģnced. To the figures above quoted as indicating the annual export value of the Queensland Oyster Fisheries, almost one-half as much again may be added as representing the home consumption of the bivalve, and which brings the value of the total annual average output of the fishery to some $£ 12,000$.

Though occupying a considerably lower position in the scale of actual annual value as compared with the fisheries of pearlshell and bêche-de-mer, the revenue accruing to the Government from the oyster fisheries and in association more particularly with the excellently organised system of leasing and licensing sections, banks, and grounds as private fisheries, is very considerably in excess of that derived from the two first-named industries, being represented during the past year by a net revenue of close upon $£ 4,500$. So soon as the Bill now framed is passed, and which has been prepared with the object of providing facilities for the establishment of corresponding private pearlshell and bêche-de-mer fisheries, a more proportionate approximation of the respective revenues may undoubtedly be anticipated.

\section{TARIETIES OF COMMERCIAL AND EDIBLE OYSTERS OF QUEENSLAND.}

There is but one specific form of Queensland oyster that receives serious consideration from a purely commercial standpoint. This oyster is the species commonly sold in the adjacent colonies under the title of the Queensland "rock oyster," and the technical name of which is Ostrea glomerata. Apart from this form, which, as hereafter shown, embraces a large number of modifications, there are several specific types of oysters indigenous to Queensland waters which, while not sufficiently abundant or possessing other disqualifications for the ordinary export trade, are wholesome eating, and are utilised more or less extensively for food.

The largest edible form of oyster found in Queensland waters is distinguished by the title of the coxcomb oyster-Ostrea cristi-galli-so-called from the regular zigzag undulations of the outer edge of its interlocking valves having some resemblance to a coxcomb. An illustration of this species wili be found at Plate III., Fig 2. A pair of the ponderous shells of the coxcomb oyster not unfrequently weigh as much as from 5 to $7 \mathrm{lb}$, and have a diameter of from 8 to 12 inches. The species is an essentially salt water form, and limited in its distribution to the tropies. It grows plentifully among the coral reefs of Torres Straits, and the Great Barrier system in either an entirely submerged condition, or, where exposed to atmospheric influences, at ordinary spring tides. Under these last-named conditions I have

C. A. $62-1891$.

observed 
observed it in especial abundance on the fringing coral reefs surrounding what are $\mathrm{known}$ as $\mathbf{M}$ and $\mathbf{N}$ Islands, belonging to the Northumberland Group, eastward of Mackay. This oyster is also to be seen in some quantities in situ, but no longer alive, on the dead and apparently raised coral reef on the west side of Magnetic Island, facing Townsville. As an edible variety the coxcomb oyster is somewhat large a cooked condition. A smaller variety of coxcomb oyster is not unfrequently obtained from deeper water in Torres Straits attached to the branches of the blek coral, Antipathes, and other zoophytes. It is remarkable for its production of finger-like projections from the back of the attached valve. With the aid of these projections it retains a secure grasp on its chosen fulcrum, though at the same time this hold may be so loose that the shell may be slipped to and fro on its supporting base. This variety of oyster would appear to be identical with the Ostrea folium of Linnæus originally reported from the Indian Ocean.

The second largest species of edible Queensland oyster is also an essentially marine type, and limited in its distribution to the tropical districts. It varies considerably in form, and may be either simply ovate, with/a broader distal margin or boat-shaped with pointed ends, as, shown in the several figures of Plates II and IV. illustrative of this type. The larger individual shells of this species not unfrequently mensure as much as 6 or 7 inches in their longest diameter. Its edges, in contradistinction to the preceding species, are usually perfectly even, or only slightly indented. A notable feature of this oyster pre vell. Its colour externally is usually a light slate-orey, and,

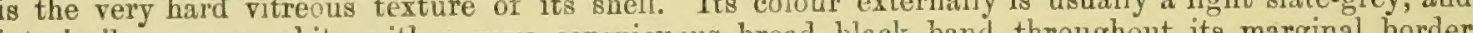
interiorily, a pure white with a very conspicuous broad black band throughout its marginal border In association with this last-named feature it has received the name of the black-edged oyster, Ostrea nigro-marginata. While by no means an unpalatable oyster in the raw condition, it, like the preceding species, finds greater favour in a stew or scallop. The black-edged oyster flourishes side by side with the form next noticed, Ostrea mordax, throughout the reefs and islands of the Great Barrier system, and is particularly large and abundant on the rocky foreshores of Adolphus and other islands in the vicinity of the Albany Pass, Torres Straits, and from whence it is extensively obtained as a seasonable delicacy for the settlement at Somerset. The hardness of the shells of this species, and the difficulty of detaching it from the rocks without fracture, even with the aid of hammer and cold-chisel, preclude its utilisation for commercial purposes in the ordinary manner, though from its size and abundance in many localities it might, in common with the form next described, be profitably canner or otherwise preserved. In illustration of the substantial dimensions to which this oyster attains, it may be mentioned that the hollow shell, illustrated by Plate IV., Fig. 1, was found to have a holding capacity of four fluid ounces or one-quarter of a pound of oyster meat.

The third species of edible oyster, other than the ordinary commercial type, indigenous to Queensland is the so-called Ostrea mordax, of Gould. Its area of distribution is a much wider one than that of the two preceding types, it being found abundantly throughout the whole length of the Queensland coast-line, from (ape York, in the extreme north, to the New South Wales boundary at the Tweed Heads. It has also been recorded from Fiji, Samoa, and other island groups in the Pacific Ocean.

While enjoying so extensive an area of distribution, Ostrea mordax may be said to attain to its finest or maximum development among the coral reefs and islets of the tropical coast-line of eastern Australia, and from its remarkable abundance in this region it may be appropriately, and is hereafter distinguished by the suggestive popular title of the Coral Rock Oyster. In contradistinction to the ordinary rock oyster of commerce, this Coral Rock species is an essentially marine type, attaining to its most luxuriant growth among the reefs and islets of the Great Barrier system, far remote from fresh water influences, and rarely overstepping the boundary limit of pure salt water in its area of distribution along the rocky headlands on the mainland seaboard. In this latter situation it not unfrequently grows as abundantly and under conditions closely simulating those represented in the typical illustration given at Plate VII., Fig. 1, of the rock variety of growth of Ostrea glomerata. The zone of growth most affected by Ostrea mordax on either the natural rocks, upheaved reefs, or stranded coral boulders, is coincident with that of half-tide mark, and I have not so far, by either practical investigation or inquiry, obtaned information concerning any instance in which this oyster has been found growing beneath, or even at as low, a level as ordinary low-tide mark.

The characteristic features of Ostrea mordax, in its most typical form, are its normally elongate triangular contour, the very evenly lobate edges of the interlocking shells, and the opaque purplish-pink hue of their external surface. Another peculiarity of this species as compared with the ordinary commercial oyster, $O$. glomerata, which it often closely resembles in size and shape, is the circumstance that it is almost always affixed to its rocky support by its left valve, while the last-named form is as invariably affixed by its right one. The flattened, freely movable so-called opercular valve is in a corresponding manner developed on the right side in Ostrea mordax, and on the left one in $O$. glomerata. An additional point of distinction between the shells of these two species is furnished by the circumstance that the scar or impression of the attachment of the large adductor muscle in $O$. mordax is set very much further back, or towards the distal or growing edges of the shells, than obtains in 0 . glomerata; this scar, moreover, in the opereular valve is more usuallv of a deep-black hue, while in the last-named species, though occasionally of a darker tint than the surrounding nacre, it is more often colourless.

While the shape as above described represents the most typical form of Ostrea mordax, it is subject to almost as considerable a latitude of variation as the ordinary commercial oyster, 0 . glomerata. This variation is the effect of its efforts to adapt its shape to that of its environment, and the shells may vary in consequence from an almost circular to an abnormally elongate contour. A yet more conspicuous modification of the very variable species is one in which the hinge or butt-end of the attached valve is produced into a long hollow beak, which is found, on opening the oyster, to contain a very considerable amount of meat. This beaked variety would appeax to be identical with the form upon which the specific title of Ostrea cucullata was originally conferred. Illustrations of this beaked variety, and also of the normal form of Ostrea mordax, are given at Plate II., Figs. 1 to 4 . A characteristic feature of the species under notice, so far unreferred to, is the one which, notwithstanding its excellent edible qualities, disqualifies it from occupying a place in the leading markets beside the more familiar commercial varieties. This disqualifying feature is represented by the tenacity and extensiveness of its union to its rocky support, and which is almost invariably coineident with the entire external superficies of the adherent shells. As a necessary consequence much labour is requisite to separate them from their attachment, and in the 
operation they are so liable to injury that, if packed in bulk and transported to long distances, a large percentage would die and engender a rapid mortality among the survivors. The species is nevertheless brought into some of the coast towns, such as Rockhampton and Gladstone, and there realises a price corresponding with that of the ordinary commercial form. It is a question whether this oyster, Ostrea mordax, might not be turned to more profitable account, by tinning or otherwise, by its collection and conservation at temporarily-established stations in the immediate vicinity of its most abundant development.

In dimensions the Coral Rock oyster rarely exceeds a length of 3 inches, and the lower or concave shells in the finest examples examined were found to possess a holding capacity of one and a-half fluid ounces. The reproductive phenomena of the species have been found by me to be essentially identical with those hereafter described of the ordinary commercial species, Ostrea glomerata, there being no incubation of the brood within the mantle cavity as obtains in the more southern mud oyster, Ostrea edulis.

A small species of oyster which is tolerably abundant in various parts of Moreton Bay, and which has in some instances encroached upon and taken possession of banks formerly oceupied by the ordinary commercial species, is the Ostrea crenutifera, of Sowerby. This species is usually less than one-half of the size of the commercial oyster, and, while somewhat resembling it in general shape, may be distinguished from that form by the more numerous, acuminately pointed denticulations of the peripheral border, which are continuous, as in 0 . cristi-galli, with raised ridges of the external surface of the shell, and radiate from the hinge or umbone to the periphery. Like Ostrea mordax last described, it is usually attached by the left valve. The colour of the shells of this species are also very distinct, being of a uniform grayishwhite externally, and greenish within, the characteristic purple tints of 0 . glomerata being altogether wanting. Being too small for commercial purposes, the increase of Ostrea crenutifera on the banks should, as far as practicable, be kept down, as, if left undisturbed, it will spread over the most favourable breeding and spatting grounds, in addition to appropriating food material that would otherwise contribute to the nourishment of the more valuablespecies. Illustrations of this diminutive oyster are given at Plate II., Figs. 5 to 7.

My attention has recently been directed by Captain Sykes, the Harbour Master of Rockhampton, to an exceedingly remarkable variety of oyster, in some respects resembling Ostrea mordax, that occurs on Rocky Island, off Keppel Bay, and which is illustrated by Figs. 2 to 4 of Plate IV. In this instance the hollow beak-like prolongation or umbone of the attached shell, alluded to in connection with the variety cucullata figured at Plare II., Fig. 2, is so abnormally developed that the movable or opercular valve presents the aspect of a small hinged lid set upon the summit of an elongate corrugated tube. In the upper of the two examples figured the relative dimensions of the two shells are so disproportionate that while the right or opercular one measures just over an inch in its longest diameter, the left or attached shell measures from its free edge to its base no less than six inches. This extraordinary modification is apparently brought about through the oysters being crowded close together with no room for lateral expansion, all growth being in consequence associated with the vertical elongation of the attached valve. As shown in the diagrammatic sectional view of such an oyster given at Fig. 3 of the same Plate, the cavity occupied by the living oyster extends through the anterior third only of the entire shell, the remaining or basal two-thirds consisting of concentric cellular lamince that represent its suecessive growth-lines.

With respect to the shape and proportions of its component shells, this tubular oyster bears a remarkable resemblance to a fossil group of bivalve mollusca known as the Hippuritidœ, and which are peculiarly characteristic of the cretaceous epoch. In the account of that family contained in Woodward's "Manual of the Mollusca," the portion of a closely analogous oyster is figured under the title of Ostvea cornucopia, a species originally established by Lamarck. The original figures of Lamarck's type, however, given at Plate 181, Figs. 4 and 5, of the "Encyclopedia Methodique," published in the year 1827, represent a rostrate oyster more nearly resembling the form of 0 . mordax, illustrated at Plate II., Figs. 2 and 3 of this report, and which I identify with the Ostrea cucullata, of Born. In a foot-note to the latest edition of Lamarck's " Animaux Sans Vertebres," Vol, VII, p. 230, 1836, the editors maintain, moreover, that Ostrea cornucopice and $O$. cucullata, as represented by the Paris Museum types, are varieties only of one and the same species. In the same manner that the beaked cucullata has been shown to represent a modification only of the ordinary Ostrea mordax, the very elongated tubular form here figured and described may possibly represent an exaggerated growth of the rariety cucullata. From an examination, however, of a very considerable number of specimens of all ages, and in all of which the tubular development of the attached shell is equally pronounced, I am inclined to regard it as a distinct species for which the name of Ostrea cornucopia-assuming it to be identical with Woodward's type of the same name-may be most appropriately retained. Among other subsidiary characters, which may be cited as indicative of the close relationship of this variety comncopice with the ordinary Ostrea mordax stock, is that of the same peculiar opaque purplish-pink of the external surface of the shells, with which is combined a corresponding striate sculpturing of microscopic fineness The scar-like marking forming the attachment of the adductor muscle on the opercular valve is also invariably of a dense black hue. The associated clusters of this remarkable oyster, when viewed superficially, with little besides the opereular shells visible, can in no way. be distinguished from the ordinary growth of Ostrea mordax, and it is only on breaking them asunder and exposing the abnormally elongated lower valves that their distinctness becomes apparent. The aspect and flavour of the meat of this oyster also corresponds with that of the ordinary mordax, and of which from within the deeply excavated lower valve a much larger morsel is to be extracted than outward appearances at first sight promise.

An oyster apparently agreeing in all essential respects with the Ostrea conncopice, here figured and described, has been reported to me by Captain Sykes as occurring on the Locust Rock, Sweer's Island, in the Gulf of Carpentaria. Further investigation will not improbably lead to its discovery in some abundance on the Queensland coast-line, and in which case it is qualified, from a utilitarian standpoint, to occupy a position equal with that of its nearest allied congener, Ostrea mordax.

Although an oyster identical with the so-called mud oyster, Ostrea edulis, of the more southern colonies has not been obtained from Queensland waters, a species bearing some resemblance to it has been sparingly procured by me with the aid of the dredge in Moreton Bay, and is not infrequently washed up in a much eroded state on the outside beaches. A highly characteristic feature of this species is the single large indentation of its free margin, and which gives to its otherwiso sub-orbicular shells a saddle-shaped contour. It has also a peculiarly thickened margin, the outer edge of which when fresh from the sea is coloured a delicate rose pink. A figure of a single valve of this oyster, and also a profile 
view of the conjoined shells, showing their characteristic curvature, are given at Plate IV., Figs. 4 and 5. It not having been found possible to identify this oyster with any of the species hitherto included in the Australian list, it is here proposed to provisionally associate with it the title of the Saddle OysterOstrea sellaformis. The largest specimens so far observed measured as much as 4 or 5 inches in diameter, or a size calculated to yield a substantial amount of meat. Although met with as isolated individuals only in Moreton Bay, it may not improbably grow in some profusion and in an associated condition in the outside waters.

Among the species of oysters occurring locally on the Queensland coast, but which are of too small a size for commercial purposes, I may make mention of the Ostrea spinosa of Quoy, which I have observed in some abundance on the rocky shores of Curtis Island in Keppel Bay, and also in Wide Bay. It adheres firmly to the rocks, and is covered with elongated spinous processes, somewhat resembling those of the Thorny Clams, genus Spondylus. A small, corrugated, red-shelled oyster that grows sparingly in deep water in various parts of Moreton Bay is known technically by the title of Ostrea circumsuta.

A species of bivalve classed among oysters in popular terminilogy, but which belongs to the genus Spondylus, previously referred to, demands brief attention with reference to the fact that it is rery unwholesome eating, if not absolutely poisonous. The species, while occurring as far south as Moreton Bay is most abundant among the coral reefs of the tropical coast-line. It may be easily recognised by the symmetrical ovate shape and convexity of its component shells, the lower or attached valve of the two being particularly deep and cup-like, and by the peculiar formation of the hinge-joint, the shelly teeth of which so interlock with one another that, while the valves open and close with the greatest readiness, they cannot be separated from one another without force, even after the death of the animal and disintegration of the connecting ligaments. The flesh of this false oyster when opened is of a pale pinkish hue. If partaken of in any quantity, in mistake for some ordinary edible varietv, severe purging and nausea usually ensues. In order to further facilitate the recognition and aroidance of this unwholesome species, a characteristic figure of it is given at Plate II., Fig. 8.

\section{THE ORDINARY COMMERCIAL OYSTER, OSTREA GLOMERATA-ITS INDIVIDUAL MODIFICATIONS.}

The ordinary commercial oyster of Queensland, with which the appellation of the "Rock Oyster" is most popularly associated, is best known scientifically as the Ostrea glomerata, of Grould. This bivalve, however, is subject to such an infinity of individual variations, dependent upon its special conditions of growth and environment, that some concologists have been led to confer a separate specific name upon each most prominent variety. Since, however, intermediate modifications abound that unite these at first sight divergent types into one harmonious series, the latest scientific opinion is in favour of including the whole within the single specific title above cited.

The diagnostic characters of this tvpical rock oyster, Ostrea glomerata, as embodied in Reeves's original description, are as follows:- "Shell thick, irregular, sharp-ribbed, with the margin dentated or lobed, very inequivalve; upper valve opercular, compressed, wrinkled, with thick concentric laminco lower valve eucullated, purple externally, white within, edged with purple or black; lateral margins denticulated; hinge generally attenuated, produced, pointed."

That modification of the species that is popularly known as the dredge or drift oyster, with reference to the circumstance that it inhabits deeper water, from which it is collected with the dredge, has had conferred upon it by Sowerly the technical title of Ostrea subtrigona. Its distinctive features as compared with those of 0. glomerata are thus enumerated by the authority quoted :-

"Shell subtrigonal, oblong, or subquadrate, ponderous, rather narrowed towards the umbones, broad at the ventral margin, quadrate; margin strongly plicated, lower valve deep, greenish white, edged slightly with purple; without, radiately plicated, concentrically banded with fawn and purple; hinge acuminated, sides crenulated near the hinge. The sculpture of the shell is bold and large, and the square character of the ventral margin is striking."

Oyster shells possessing the characteristic features incorporated in the two foregoing diagnoses may be found growing side by side in the same cluster, collected from a bank exposed at ordinary low tide, or if dredged from a depth of three or four fathoms. A tendency, nevertheless, prevails with the shallow water, tide-exposed racial stock to develop the more luxuriantly frilled and convoluted marginal border and brighter colours associated with the typical Ostrea glomerata, while with those growing in deeper water a smoother and more ponderous form, with often an abnormally elongated contour, and a more or less complete absence of the conspicuous colouration characteristic of the shells exposed to light and air, is found to predominate. The several specimens figured in Plate 1 have been selected for the purpose of illustrating some of the most characteristic modifications of this exceedingly variable species. At Fig. 1 is represented a cluster of the most esteemed marketable form, or typical glomerata, taken off a cultivated bank; Figs. 2 and 3 depict the concave adherent or so-called lower valve, and the flat, movable, or opereular valve of a similar oyster separated in order to show the internal structure and position of the muscular scar.

Fig. 4 has been chosen to illustrate a form very prevalent among the oysters taken from deep water or dredge sections, and in which the prolongation and smoothness of the component shells are more conspicuously pronounced than in the typical dredge or drift variety associated in the foregoing diagnosis with the title of Ostrea subrrigona. This abnormal elongation, it would seem reasonable to anticipate, exhibits a disposition on the part of the molluse to grow upwards towards the light, much after the manner of a light-starved plant. That this tendency to elongate may be manifested at an early period in the oyster's life is well shown by the brood-cluster represented at Fig. 5 of the same Plate, and in which a number of slender elongated shells are attached vertically to the dead valve of a Parallelopipidon. These young oysters were dredged from a depth of four fathoms in Moreton Bay. The same dredge haul that yielded these specimens brought up, however, a much more considerable number of brood agreeing strictly in contour with the typical form of Ostrea glomerata. Adult clusters obtained from a similar depth, moreover, containing the normal and the elongated modification in the same oroup.

A third notable variety of the ordinary rock oyster, Ostrea glomerata, is most typical of the northern area of its distribution. It is remarkable for its almost circular or sub-orbicular contour, with prominent radiating frillings and, most irequently, deep cup-like exeavation of the attached shell. This type of oyster is abundantly represented in the extensive banks and reefs in the neighbourhood of Keppel Bay, 
and is also dominant among those growing on the mangrores in the Endeavour River, near Cooktown. It never attains to the large size of its southern congener, a shell having the capacity of a single fluid ounce being of abnormal dimensions. This modified form would appear to be indentical with the type upon which, on insufficient evidence, the so-called Ostrea mytiloides, of Lamarck, has been established. That it is a variety only, however, of the common species, and not a distinct form, is abundantly shown by the fact that oysters approaching the normal triangular outline occur among them, while the orbicular variation, on the other hand, may not unfrequently be detected growing among the typical triangular southern race. Representative illustrations of this characteristic orbicular variety will be found at Plate I., Figs. 6 and 7. Within the circle covered by the ordinary triangular, the orbicular, and the abnormally elongate modifications of Ostrea glomerata that have now been enumerated, the inclusion of any of the numerous intermediate local variations that occur will be an easy task.

\section{COLLECTIVE CONDITIONS OF GROWTH.}

Among the several natural phases of growth under which the commercial oysters of Queensland occur in marketable quantity and condition, that in which the bivalve spreads itself over extensive level banks that are more or less uncovered at low water represents the most important. These "bank oysters" may be attached to stones or dead oyster shells lnnown as culteh, or, as still more frequently happens, to the living shells of a peculiar species of whelk, Potamides ebenimus, Brug., whose name, with the aborigines of Moreton Bay, is that of "Toondah." This whelk, which grows to a length of three or four inches, is essentially herbivorous, feeding on the Confervæ, lower algœ, and other vegetable organisms that abound on the mud flats so favourable to the growth of the ovster. The free-swimming orster embryos, or "spat" become attached in large numbers to the exposed dorsal surfaces of the whelk's shell, and are carried about with it among the most luxuriant pasture grounds. Within a few months' time the oysters have increased to such a size and weight that the whelk is no longer able to travel with its burden, and where the ground is soft sinks into the mud and perishes, leaving the living crown of oysters to mark the position of its interment. Of the number of oysters originally adhering to the whelk, some four or five, representing the survival of the fittest, usually grow to maturity and marketable size. Included among some very fine examples of whelk-oyster growth placed at my disposal by Dr. Bancroft, I found that the load of oysters carried by the living whelk frequently weighed as much or more than half-a-pound, while the whelk itself barely weighed an ounce.

A typical illustration of an oyster bank, representing one of the rich oyster grounds of the Bribie Passage, Moreton Bay, is given at Plate V., Fig. 1. It is noteworthy that the banks in this district are formed more exclusively of ofsters attached to ironstone pebbles lying upon a substratum of gravel and tenacious mud. They enjoy a high reputation for their shape, size, and flavour. Oyster banks of the character described exist in the most luxuriant natural conditions throughout Moreton and Wide Bays, the northernmost point of their occurrence being Rodd Harbour and "Seven-Mile Creek," a little south of Gladstone and Port Curtis. The oysters on these northern beds grow under conditions, on whelks or on separate shell or stone bases, precisely parallel with those of their southern congeners, but do not in that higher latitude attain to so large a size. The experiment of transporting these smaller northern oysters to southern banks is now under trial, with every promise of a successful issue, though the considerable interval of, approximately, twelve months has apparently to elapse before the new growth commences that is required to convert them to marketable dimensions.

Concerning bank oysters generally. it may be mentioned here that this form of growth represents the most important from a commereial standpoint. Not only are the largest numbers of oysters sent to market taken from the banks, but it at the same time furnishes employment and a livelihood to a very extensive section of the community. In this connection it may be affirmed that probably in no other country in the world is so healthy, congenial, and unlaborious a means of earuing a substantial competency open to, and turned to practical account by, all classes as that of bank orster culture in the Queensland oyster-producing districts of Moreton or Wide Bays. With a nominal rental payable for the ground cultivated and occupied for a homestead, a climate that permits of dispensing with all but the most necessary form of raiment, and fish procurable in such abundance as to substantially minimise the butcher's bill, no more perfect terrestrial elrsium is probably at the disposal of small capitalists having sufficient means for the supply of their most immediate necessities during that first year or two that must elapse before their oyster crops bave increased to a remunerative extent

The description of growth ranking next in importance to the bank series constitute what are known as oyster reefs. These in their most typical form consist of solid masses of oysters that may be several feet in thickness, raised to a ligher level than the banks-the tops being exposed at about onequarter ebb. As a rule, the upper erust, representing some five or six to twelve inches in thickness alone of these reefs, consists of living oysters, the substratum being composed of the dead shells of their ancestors. These reefs in their most characteristic state rest simply on a clay or gravel basis, but are not unfrequently associated with a rocky outerop as their starting point. Oyster reefs, while formerly abounding in Moreton and Wide Bavs, are now represented in greatly diminished numbers. Their constituent oysters, in consequence of their crowded growth, are of small dimensions, but on being broken apart and distributed on the banks soon increase to a marketable size. Such reefs have consequently formed one of the main sources for the collection of stock for cultivation on the banks, and this to such an extent that few if any reefs are to be fourd in their pristine massive condition throughout the oyster grounds of the Southern district. A highly characteristic illustration of a typical virgin oyster reef selected from those which occur in the neighbourhood of "The Narrows," between Port Curtis and Keppel Bay, is given at Plate V., Fig. 2. The oysters in this reef are accumulated in a solid mass four or five feet thick, their density being well shown by the portion which has been undermined by the current and broken away from the parent mass. The originally horizontal superficial area thereby exposed serves also to illustrate the rounded or sub-orbicular shape previously alluded to, that usually characterise the growth of oysters where massed together in this more northern district. The basis of this luxuriant oyster reef and of otbers in the same locality consists chiefly of gravel and coarse sand overlaying a tenacious clav, larger pebbles or small drift boulders trausported through the agency of flood currents being here and there interspersed among the general mass.

Typical rock oysters, wherein the bivalve occurs in masses attached to rocks, are well represented in the illustration Plate VII. Fig. 1, reproducing the rocky outcrop with attached oysters at Burleigh Head, near the mouth of Tullebuggera Creek, a little to the south of Southport. The oysters growing under these conditions, though smaller in size than the bankers, are often of a deep cuppy shape and 
excellent in quality. Like those growing on the reefs they are well adapted for separation and cultivation on the banks, though the tenacity with which they adhere to their rocky basis involves considerable more care and labour in their detachment.

What are known as "Mangrove" oysters represent an important item in the Queensland growth conditions of Ostrea glomerata. These are the oysters with which originated the supposed travellers' tales of earlier days concerning oysters growing upon trees. The most typical and commercially important phase of mangrove oyster growth is represented by those instances in which the oysters start to grow on the exposed roots and respiratory shoots or so-called "cobblers'-pegs" of the white mangrove, Avicennia officinalis, and by the process of accumulation may increase to such an extent as to constitute under the most favourable circumstances massive banks scarcely less prolific than the typical reefs previously described. The initial form of such a mangrove oyster bank, together with the perfected luxuriance to which it is capable of attaining, is illustrated by Plate VI., Fig. 1, and Plate VII., Fig 2, representing reproductions of selected photographic views taken respectively in Moreton and Keppel Bays. Where growing in the prolific manner represented on Plate VII., they constitute, as in the case of the typical reefs previously described, valuable material for segregation and artificial cultivation on the banks.

A second and somewhat less prolific variety of mangrove oyster growth is that in which the species is found attached to the luxuriantly ramifying aerial roots of the red or orange mangrove, Rhizophora mucronata, as illustrated in Plate VI., Fig. 2. Oysters on this description of mangrove more commonly occur in the northern area of distribution of the species, and in such localities as the mouth of the Endeavour River, near Cooktown, and at Bowen, Port Denison, constitute the almost exclusive representative variety of the species. This mangrove oyster occurs also in some abundance in certain parts of Wide Bay such as the vicinity of the South Head. In consequence of its adaptation of contour to the shape of its supporting fulchra, this oyster is apt to develope a very irregular form of growth; if, however, moved at an early stage of its existence and spread out under favourable conditions for culture on the banks, it has been found by systematic oyster growers to well repay such attention. This being the experience gained on the Wide Bay oyster grounds, it may be anticipated that successful results would also accompany a like treatment of the variety in its natural habitat further North. This anticipation is supported by the circumstances that oysters of larger and edible dimensions and quality are to be gathered from among the fallen débris lying around the mangrove trees, and where living more or less separated from one another, they have room to expand. Giving due weight to this fact I am of the opinion that remunerative banks, productive of oysters in at least sufficient quantities for local consumption, might be established, with stock derived from the mangroves, in these more Northern districts. In the establishment of such experimental banks attention should be given to imitating as nearly as possible Nature's own pattern, the banks being formed, not on the open sun-exposed flats but within that umbrageous shelter of the mangrove trees where the species attains to its finest development in these higher latitudes. The conditions indicated obtain on a sufficiently extensive scale for the practical application of the above suggestions in both the estuary of the Endeavour River and at the mouths of the several ereeks debouching into Port Denison, in the neighbourhood of Bowen.

I have been recently informed by Mr. Yeo, the manager of the Moreton Bay Oyster Company, that the above described variety of mangrove oyster grows so luxuriantly in favourable localities in the neighbourhood of Rodd Harbour that as many as twenty or thirty bags of oysters suitable for cultivation on the banks have been gathered by their agents from a single tree.

The collective growth forms of Ostrea glomerata, known as dredge and drift oysters, remain to be noticed. The first-named title is applied generally to all oysters growing below the level of usual ebb tide, that of drift oysters being more exclusively associated with those lying loose and separately at the bottom of the water, and which are supposed to have been washed from off the banks or beds, and to drift here and there at the mercy of the prevailing currents. The tendency of the dredge, or deep water oyster, to develop a more elongate shape with a much smoother and less crenulated maryinal border has been referred to on a previous page. "With the typical "drift" variety the tendency, through continued erosion, to develop an abnormally massive shell is especially noteworthy, instances occasionally occurring in which the lower or right valve weighs as much as half a pound avoirdupois. The concavity of such a shell is rarely of sufficient size as to contain more than a single fluid ounce, while the corresponding shell of a large cultivated "bank" oyster, having an internal capacity of two fluid ounces, yields an average weight of searcely three ounces. Dredge and drift, as compared with bank, oysters contribute to a less extent to the oyster trade of Queensland, the relative proportions so far as it can be ascertained, while formerly considerably larger, being now about 20 per cent. In this respect the Queensland oyster fisheries present a marked contrast to those of the neighbouring colony of New South Wales, and in which the dredge and drift varieties have until within recent times represented the most important commercial factor. Among the arguments that have been advanced in favour of the specific distinctness of the deep-water oyster, or Ostrea subtrigona, as it is designated by those who advocate its distinction, is the one that this deep-water form will not live if transported to the tidally-exposed banks, nor the bank variety if consigned to deep water. If the transition is made unseasonably, unfavourable results are likely to ensue. Where, however, the change is judiciously effected, no difficulty is experienced in cultivating dredge or drift oysters on the ordinary banks, or vice versâ. In various localities in Moreton Bay, and notably at the Breakwater in Nerang Creek, oysters grow in a continuous sloping series from a depth in which they are covered by a fathom or more of water to the tops of rocks that are dry with every ebb. Orsters taken from these exposed rocks are, moreover, systematically and successfully laid down as "cultivation" on a neighbouring dredge section, where they are covered by at least two fathoms of water. No more practical evidence, probably, could be furnished in demonstration of the specific identity of the deepwater and tidally-exposed series. Parallel illustrations of a species of oyster adapting itself to the varied conditions of either total or partial submersion are afforded by the typical European oyster, Ostrea edulis, or its Australian variety, $O$. angasi, as it occurs in the more southern colonies. In the former instances it may be dredged in the open sea at a depth of as much as twenty fathoms, being then represented by the large rough form commereially known as Channel oysters, or it may be gathered somewhat rarely in England, but more abundantly in the warmer waters of the Channel Islands, or on the neighbouring coast of France, adhering to the rocks after the manner of Ostrea glomerata. It is this same species, moreover, in its coarser natural form, ordinarily taken with the dredge, that is cultivated on so extensive a scale on the tidally exposed foreshores of France, or that is transformed, through a long and tedious course of manipulation, into the costly world. 
renowned Colchester or Whitstable "Native." The fact that the drift or deep-water form of Ostrea glomerata, as it occurs in Australian waters, is most commonly found separated by a considerable interval of space from its congener of the rocks or banks, is probably explained by the circumstance that the strong current or scour which is essential for its healthy existence is wanting in the intermediate barren areas. A deep well-scoured central channel in which the molluse flourishes is commonly separated from the equally clean tidally-exposed, and current-swept litoral margin by an intervening area of stiller water, within which mud and sedimentary matters accumulate to an extent rendering it unsuited for oyster growth.

In connection with the subject of "dredge" oysters, it is worthy of mention that the theory has been advanced that profitable beds of the ordinary commercial variety, Ostrea glomerata, probably exist in deep water on the open coast-line of Queensland and New south Wales. The evidence adduced in support of this theory is founded on the circumstance that oysters have been recently dredged under such conditions off the Victorian coast-line in connection with the prospecting cruise of the Victorian Government steamer "Lady Loch." The successful results there obtained were the outcome of a report I made on the Victorian Oyster Fisheries, and in which, in consequence of the traces of the existence of oysters observed by me along the Ninety-mile Beach and other portions of the coast, I foretold their presence in extensive beds, and recommended to the Government that experimental dredging operations should be undertaken with the view of their discovery. The species of oyster in this instance, however, was the so-called mud oyster, Ostrea edulis, var. Angasi, of which the largest natural beds are found in the open sea. The Queensland and New South Wales commercial form, Ostrea glomerata, is an essentially estuarine or brackish water type, and which, so far as my investigations and inquiries have extended, is never met with in water that is permanently salt. There is consequently, I consider, little or no chance of success attending any attempt that might be instituted to dredge for this oyster on the open sea-board. With relation to the salinity of the water most favourable for the growth of the Queensland commercial oyster, I have found, in association with a prolonged series of investigations, that a mixture of one portion of fresh water to four of standard salt water represents the most normal conditions under which it flourishes. In times of drought it frequently happens that the oysters in many localities are immersed for considerable periods in water that is entirely salt, and converselyduring floods in purely fresh water. Should this latter condition, however, obtain for over a week, disastrous results usually ensue, more especially with relation to the immature stock.

Experiments were also undertaken by me with the view of ascertaining the action of water of varying density upon the newly born oyster embryos or spat. Of ova and milt commingled with one another in purely salt water it was found that but a very small portion of the ova were fructified, and the subsequent development of these few proceeded very slowly. Another series placed in water consisting of an equal proportion of salt and fresh exhibited the most active vitality, all the ova being fertilised and speeding quickly on their developmental career. In a third series experimented with, the proportions of water used were one part of salt water to three of fresh. In this instance the ova were entirely deprived of life, and soon commenced to disintegrate. This last experiment assists much towards demonstrating the deleterious action exerted by floods on the embryonic brood, and where the proportion of fresh water, as in the example tested, is greatly in excess of the salt. It is at the same time worthy of remark that the access of flood water appears to give a pronounced stimulus to the oyster's reproductive facuities, an abundant fall of spat commonly following after the advent of a flood, and thus compensating for its ill-effects upon the previously developed brood.

\section{ARTIFICIAL CULTIVATION.}

The artificial culture of oysters, as understood and practised in connection with the Queensland Oyster Fisheries, and as applied to the single species, Ostrea glomerata, cousists essentially of collecting the immature brood, locally known as "cultivation," and separating and spreading it out on banks and beds where the conditions are more favourable for its development to marketable dimensions. One of the most important sources from which this ware or "cultivation" is derived, is represented by the tidally-exposed reefs described on a preceding page, and from whence, with the least expenditure of labour, vast quantities can be speedily collected. Not only have the oyster reefs and banks throughout Moreton and Wide Bays been laid heavily under contribution for the supply of this "cultivation," but supplies for the same purpose are now being imported from as far north as Rodd Harbour and Keppel Bay.

Such is the enormous fecundity of the Queensland commercial oyster, and the extent of the areas available for the adherence and development of the spat, that little or no occasion has hitherto arisen for resort to the more elaborate methods of oyster cultivation practised in European waters, and which comprises as its most fundamental principle the provision of special apparatus for the catchment of the embryo brood. Sufficient, however, as the supply may be to meet the existing demand, it may be predicted that, with the increased home consumption and greatly extended export trade that may be reasonably anticipated within the next decade, some more scientific method than that hitherto in force will be in request for saving some portion of the vast amount of oyster spat annually produced, which, under present conditions, is literally lost at sea. By the lowest estimate arrived at by trustworthy investigators it would appear that each mature female oyster produces at least from 2,000,000 to $3,000,000$ embryos at the annual breeding season. Of the vast number thus produced it has been further estimated by Mobius concerning the European species, Ostrea edulis, that less than one individual oyster in each of these million embryos runs the gauntlet of the innumerable perils that beset its career, and arrives at maturity. The greatest amount of mortality that decimates this embryo host is undoubtedly associated with its failure, after the maturation of its shell, to fall upon ground or materials to which it is able to secure an effective anchorage. Unless the surface on which it falls is clean and entirely free from slime or sediment, adhesion is not accomplished, and the embryo drifts away or sinks into the mud or sand to perish. The aim and end of the systematic methods of oyster culture in operation in European, and most notably French, waters is to encompass the salvage of the vast shoals of embryonic waifs that would naturally run to waste. The accomplishment of this highly desirable result is effected mainly through the provision of apparatus styled "collectors" that form attractive media for the adhesion of the spat. These collectors are constructed of varying form and material. From the earliest days of oyster culture the old shells or "cultch" of the oysters originally raised for the market have been systematically saved and placed upon the beds with gratifying results ; such materials constituting, in fact, one of the most natural media for the attachment of the embryo brood. Faggots of wood, best known by their French title of

"fascines," 
"fascines," have been and are still extensively used in French waters, and at the ancient oyster breeding establishment of Lake Fusaro in Italy for a similar purpose. The most efficient description of artificial spat collectors that have been invented are, however, probably those first introduced into the Erench oyster grounds by M. Coste, and which consist of a cheap form of earthen tile, the under surfaces of which are coated with Portland cement. The calcareous constituents of the cement, when set and seasoned, are so analogous to those of the parent oyster shells that the embroo brood adheres to it with equal readiness. A second form of collector, successfully employed in France, consisted of cemented boards united by their long edges in ridge-tile fashon, and being strung one above another in sets, and anchored by a stone, are allowed to float freely in the current. This "ridge-tile" form of collector was first employed by myself with fair results in connection with the Government Oyster Reserves of Tasmania, established under m supervision in the year 1885, with the object of resuscitating the at that time exhausted oyster fisheries of that colony. Figures with a description of this form of collector were published in iny report to the Tasmanian Government for that year, and, acting on the information therein contained, I am informed that similar collectors were experimentally placed on one of the cultivated banks in Moreton Bay. These collectors, as a result, were soon covered with spat, but, being set in shaliow water, they, as each tide receded, fell to the ground, and the young oysters became a ready prey to crabs and whelks. The same form of collector has also the drawback of getting water-logged and sinking to the bottom by its own weight after prolonged immersion, and when the attached brood runs the same risk of premature destruction by its natural enemies or by the accumulation of sand or mnd.

As an improvement upon and simplification of this ridge-tile collector, I subsequently made use of the rough form of boards, known throughout the Australian Colonies as "split palings." Such palings4 feet long, 8 inches wide, and 1 inch thick-were readily procurable at the low price of from eight to ten shillings per thousand. With a brick or stone attached by wire to each end on the under side, the surface between the two bricks coated with cement, and a loop of wire fixed to the upper surface to serve as a handle whereby they could be carried easily or lifted from or lowered to the bottom of the water with the aid of a boat-hook, they were found to constitute the most convenient and economic form of collector that could be desired. The bricks or stones on the under surface served the double purpose of anchoring the collectors securely to the bottom of the water, and at the same time raised the cemented surface above the reach of predatory crabs and whelks. In practical application these paling collectors were found to possess all the efficiency of the French tiles, with the adrantage of a far greater economy of cost. The tiles, with individually smaller superficial areas for the attachment of the spat, cost in France about $£ 2$ per thousand, and could scarcely be produced in Australia for double that price. In order to test the efficacy of this description of spat collector in connection with the Queensland oyster, Ostrea glomerata, a few samples were constructed and experimentally placed on ground at a spot where a few mangrove oysters already existed, near the mouth of Nerang Creek. These collectors were deposited in the month of July, 1890, and within from three to four months from that date were literally encrusted with oyster brood having shells which averaged one inch in diameter. Two months later a large portion of these oysters measured individually as much as two inches in their longest diameter, and being loosely attached by the butt-end were ripe for detachment and distribution on the ordinary cultivation banks. As many as 2,000 young oysters were thus found attached to a single collector, being the equivalent of what, in the ordinary course of development, would, by the end of another eighteen months, represent a standard two bushel-bag of marketable oysters. Photographs of these sample collectors in their newly-mado condition, and with attached oyster brood, are represented in the illustrations of Plate VIII.

Although the general employment of artificially prepared spat collectors upon the Queensland oyster banks as here described is not recommended, and would be scarcely profitable in association with the existing abundant supplies and the extensive natural spawning grounds at the disposal of the leading lessees of the oyster fisheries, there are undoubtedly circumstances and conditions under which their introduction would prove of value. With the aid of these and kindred collectors, miles of what now repregent barren unremunerative mud flats in both the Moreton and Wide Bay districts might be made to produce an abundant harvest; while to small selectors having foreshore allotments at present yielding them no return below high water-mark, they have at hand the ready means of substantially augmenting their incomes. That in the no very distant future the employment of artiticial spat collectors will be desirable, if not obligatory, as a means of supplementing the natural supplies and meeting the increased demand for both home consumption and export purposes that is likely to arise, is a conclusion, indeed, that can scarcely be avoided. The more immediate necessity of resorting to artificial methods for collecting oyster spat has, I may further observe, been strongly advocated by the Moreton Bay Iuspector, Mr. C. S. Hison. At page 4 of his report for the year 1886, among a list of amendments recommended for the better regulation of the oyster fisheries, a prominent position is allotted to that of the compulsory employment by oyster bank lessees of artificial methods of spat catchment.

It would appear desirable under the present heading to make a brief allusion to the section on oyster cultivation included in the same District Inspector's Report for the year 1890 . At pages 3 to 5 of the report referred to, extensive quotations are made from letters treating on the subject, contributed by a Sydney oyster merchant to the Sydney Press. The general tenor of these letters is to depreciate the results that have been accomplished by methods of artificial cultivation in France. These results are, in point of fact, so grossly misrepresented as to make it appear that the system is itself a failure, and that no success could attend its introduction into Australian waters. The acceptance and re-publication of these letters, in all good faith, in an official report, as embodying the latest and most accurate information on the subject of oyster culture, is necessarily calculated to mislead the public and to discourage any efforts being undertaken to profit by the highly successful results actually accomplished on the French sea-board. It is with the object only of counteracting so undesirable an influence that a brief statement of the actual facts, with accompanying statistical figures, are herewith submitted. Jn the first place, it would appear that the data upon which the letters above referred to are based were derived from the Government report on the oyster fisheries, Ireland, dating so far back as the year 1870, and at about which time, as testified to by witnesses engaged to collect evidence, the French Oyster Fisheries were undoubtedly in a very declining state. The cause of that decadence, which is fully explained in the report, but is in a most unaccountable manuer totally ignored in the documents cited, was the avariciousness of the oyster growers, who stripped their beds to such an extent to supply the markets as to leave an insufficient quantity for the purposes of propagation. This error, however, was corrected as aoon as recognised, and with the result that within a very few years the French Oyster Fisheries had not 
only regained their former position, but eclipsed previous years in productivenoss. Tho accompanying figures, derired from the French statistical returns, abundantly substautiate this statement. In the year 1873 the official value of the oyster prodnce of France was estimated at 2, 447,565 francs, or roughly

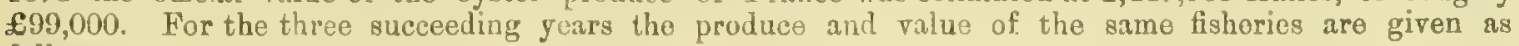
follows:-

$\begin{array}{ccc}1874 & & \text { Oysters taken of beds } \\ 104,731,350 \\ 1875 & \ldots & 227,640,212 \\ 1876 & \ldots & 335,774,070\end{array}$

Value in francs.
$7,727,000$
$11,247,416$
$13,226,296$

Eaglish equivalent.
$£ 309,080$
$£ 449,896$
$£ 529,051$.

In the year 1887, representing the latest statistics immediately arailable, the total number of oysters taken from the French fisherics is quoted at $375,000,000$, showing that the magnificent record of the year 1876 has been beaten.

Among the evidence brought forward in the Sydney letters, with the view of depreciating the efficacy of the French system, and republished in Mr. Fison's report, much stress is laid upon the circumstance that some twenty years ago the Hon. Thomas Holt, recognising the value and capabilities of that system, undertook, at an expense of some $\mathfrak{E 1 0}, 000$, though unfortunately without success, the construction of extensive culture ponds, or "claires," at George's River, New South Wales, for the cultivation of oysters on the same principle. The causes that led to the failure reported, however, were not attributable to the system, but to the fact that a species of oyster differing essentially in form, habits, and methods of propagation from the European type was experimented with. Having recently availed myself of the opportunity of inspecting these extensive "claires" constructed by Mr. Holt, I am of the opinion that they are altogether unsuited for the culture of the Queensland and New South Wales commercial oyster, Ostrea glomerata, that was the subject of experiment. On the other hand, they would in all probability prove highly suitable for that special fattening process of Ostrea edulis, for which alone these claires are utilised in France. Properly constructed, these claires take the form of shallow ponds of from twelve to eighteen inches in depth, and are so connected by means of sluices with the sea that fresh streams of salt water obtain access to them only at spring tides; the water throughout the intervening periods remains completely stagnant. It is through the culture of the French oyster under these special conditions that that green colouration of the oyster's tissues is acquired that command for it so high a price in the Paris market, such colour being due to the character of its food, which consists almost exclusively of the microscopic plants known as diatoms and the spores of the confervoid algœ. This special claire system of oyster culture is in no way suited to the Queensland oyster.

Oyster culture on the Freuch system, on the other hand, in so far as it consists of providing supplementary material or apparatus for the catchment of the redundant supplies of spat is undoubtedly worthy the attention of all oyster growers. Whether this material takes the simplest form of the returned parent shells or cultch, or of tree-branches or fascines, or cemented tiles or boards, the result to be accomplished is identical, and it resolves itself to a question simply as to which of these can be most economically or profitably employed on the areas under cultivation. In this direction it will be found that different descriptions of oyster ground yield the best results in association with diverse descriptions of collectors. On those beds and banks which are inore or less completely submerged, and over which there is a sufficient scour to prevent the accumulation of sediment, old oyster shells or cultch constitute the most convenient and efficient form of spat collector to employ. This material, however, if laid on muddy banks, or where there is an insufficient circulating stream, becomes speedily covered with slime and sediment, and is, in such condition, useless as a spat-trap. The sine quâ non of successful oyster spat deposit is the existence of a perfectly clean surface for the embryo oysters to alhere to. On the oyster grounds in English waters, such as Whitstable and Herne Bay, where the natural beds consist mainly of such old shells or cultch, its surface is continually worked over with the dredge with the express object of exposing new and clean shell surfaces for the attachment of the embryo brood.

The form of collector next demanding attention is that of fascines or fagrots, composed of boughs and branches of various sorts of timber trees. This description of cullector is essentially fitt d for employment on osster grounds where they can be kept continually floating or submerged below the surface of the water. The drawback to the use of fascines, or tree branches in any form, is their liability, on exposure to light, to become speedily coated with slimy growths that leave no foothold for the young oysters. Considerable differences are, however, manifested by distinct kinds of trees with reference to their attraction for oyster spat. The commoner Australian gums, Eucalypti, and wattles, Acacias, are apparently distasteful on account of the pungency of the essential oils and essences they continue to exude even after prolonged submersion, and are but rarely encrusted with oyster brood. The Coniferœ, including the cedars and cypress-pines and also the shea-oaks, Casuarinas, have, on the other hand, been found in practice to yield more favourable results than any other timber, and more especially in experiments conducted by me relating to the artificial propagation of the Tasmanian oyster. The readiness with which the Queensland species naturally adheres to the large branching aerial ruots of the orange mangrove, Rhizophora mucronata, w suld seem to indicate that this material would form an excellent one for the systematic construction of fascines.

To render fascines more efficacious as spat collectors, the bougbs of which they are composed are, as used in Europe, not unfrequently washed over with cement. This modified form of fascines leads to those descriptions of collectors in which cemented surfaces are exclusively emploved. The most prominent of these are the cemented tiles first employed by M. Coste, and with the aid of which miles of barren mud flats on the coast of France have been converted into mines of wealth giving employment to thousands of individuals. This description of collectors is eminently adapted, and was originally constructed, for employment on bauks or flats that are left uncovered at ebb tides, and is unsuited for manipulation beneath the water.

The peculiar advantages of cemented tiles and of all forms of collectors constructed on the same principle, consist in the fact that the relatively large cemented superficies, being on the under surface of the collector, when placed in position, it remains almost permanently clean and ready for the adhesion of the spat. They are consequently well adapted for employment on mud flats, where there is much sedimentary deposit and under conditions in which other forms of collectors would be useless.

The "split-paling" collectors, first introduced by myself in the Colony of Tasmania, as the nearest approximate substitute for tiles, which were unprocurable, except at probibitory prices, proved in all ways equal to tiles as spat collectors, and in rarious directions possessed distinct advantages, Their price 
of 10s. per 1000 rendered them cheaper for the purpose than any article previously employed. With attached wire handles they were more convenient for handling on the exposed banks, and could, in addition, be easily deposited in or raised from water of a fathom's depth. Their individually larger superficial area entailed a considerable saving of labour in their manipulation, while, as indicated on a preceding page, the circumstance of the cemented surface being raised by the attached bricks or stones some ferw inches off the ground secured to tho young oysters an immunity from the attacks of crabs, whelks, star fishes, and other enemies to which they are exposed when the cemented surface, as is the case of tiles, is in immediate contact with the ground.

The "split paling" type of spat collection, as figured in Plate VIII., is, in my opinion, after an experience of its successful cmployment under a variety of conditions, the most convenient and economic form to employ in Anstralian waters, and may be characterised as an essentially Australian product. Sawn boards may, as a matter of course, be fashioned into collectors of identical form and efficiency, but at many times their cost, the relative price of the respective materials averaging 20 feet for $1 \mathrm{~d}$. for the split palings, and $1 \frac{1}{2} d$. per foot for the sawn wood. In practical use the split palings are further found to possess an advantage over the sawn inaterial, through the roughly parted natural grain of the wood furnishing a more favourable key for the attachment of the cement. When split to order for this purpose they should average at least an inch in thickness, and have as rough a surface as it is possible to obtain. Where split paings are not procurable the rough discarded rails or boarding of any description that is usually abundant around every settlement, may be pressed into service and be made to do good duty before final condemnation for firewood. In the preparation of these collectors the palings or boards should be soaked for a day or so in the water in order that the grain may swell to its full extent before the application of the cement. Should this precaution be neglected the cement will not adhere to the wood. Salt water is as good as fresh for mixing the ccment, and, as the process may be most conveniently performed at the water's edge in the immediate neighbourhood of the beds under cultivation, this proves a distinct advantage. From experience gained by the use of these collectors in Queensland waters it may be observed that about half-tide mark represents the zone within which the most abundant harvest of spat can be gathered, and that at all times of the year, though the months of February and August are more especially propitious for its collection.

On their first attachment to the cemented collectors it will be found that the young oysters adhero to the cement by the entire surface of the attached shell, a condition of growth which obtains for the most part in the central figure of the lower group of collectors figured at Plate VIII. After attaining to about one-half of an inch in diameter, the free edges of the sbells commence to grow outwards, and this direction of their growth is continued until at an age of about six months they project an inch and a-balf or 2 jnches from the collector. At this stage the young oysters may be easily detached with or without the cement, and be laid on the banks as ordinary "cultivation." l'he collectors may then be recemented and re-laid for the catchment of a sccond crop. Cemented slates have also been found by me to prove very efficacious spat collectors, and most nearly approach the French tiles. Slates procured as an ordinary market article are too expensive for general employment. It sometimes happens, however, as occurred with the supply experimented with, that condemned lots may be obtained at but a little over the cost of carriage direct from the quarrics. In utilising slates for this purpose I bave found it most convenient for manipulation to use them in combined series, wiring sets of half a dozen or so to each side of a ridge-shaped frame constructed of light saplings cut to 4 or 5 feet lengths.

\section{DESTRUCTIVE AGENCIES AND DISEASES.}

Among the enemies from whose attacks the Queensland oyster-grower suffers serious loss of stock, the small boring whelk, Urosalpinx paiva of Crosse, must be awarded a prominent position. 'Tho destructive iufluences exerted by this molluse are parallel to those of Murex tarentinus and Nassa reticulata on the European oyster beds. The shell of the Queensland borer is much like that of the last-named European species, but is more slender, and it has a distinct violet-coloured lining to the mouth aperture. A figure of the species is given at Plate I., Figs. 10 and 11. The young oyster brood, from its earliest attached condition up to about one-half of its adult growth, is much subject to the ravages of this foe. Not unfrequently, it is so abundant and predaceous that almost the entire brood stock on a bank or from dredgings I have investigated was found to be destroyed by this borer. Mature oysters, even, are not exempt from the attacks of this enemy, one of the shells in the typical cluster illustrated by Plate I., Fig. 1, exhibiting at " $a$ " the symmetrically circular hole by which the Urosalpinx has gained access to its prey. The drilling operation is performed by these boring molluses with the aid of a toothed ribbon, technically known as the "Odontophore", which is enclosed within, but can be partly protruded from, the buccal cavity. It has been ascertained by direct experiment in connection with the European species, Ifurex tarentinus, that the molluse takes about half an hour to pierce the shell of a young oyster one month old, and eight hours to perforate a matured one of three years' growth. The only practical remedy for this destruetive pest so far cmployed is hand-picking, a tedious process which, however, can be carried into practice with considerable success on the banks, especially with the aid of children, who soon become great adepts in detecting and collecting the unwelcome intruder. By these means the borer has already been fairly exterminated in cerlain of the most carefully-cultivated banks. This same species of boring whelk has been observed by me in abundance on the oyster banks as far north as Rodd Harbour and Seven-mile Creek, and where also it takes a heavy toll on the growing brood. The interesting discovery was recently made and communicated to me by Mr. E. Kelk, of Brisbane, that another gasteropodous molluse, Natica plumbea, preys upon the Urosalpinx. This species, firured at Plate III., Figs. 3 and 4, is of larger size than the borer, with a smooth smail-like shell. In the living state a large fold of flesh, technically termed the mantle, is protruded from the shell and forms a con. tinuous border of about an inch in breadth around the creature as it crawls. With this mantle it was observed by Mr. Kelk to seize and envelop the living borers and to retain them within its folds until by muscular force it had dragged from its shell and devoured its victım's body. Should this recorded habit of Natica plumbea prove on further investigation to be its customary one, a valuable remedy for the ravages of the borer will have been discovered, and to be effected through the collection and placement on the beds of quantities of Natice to devour and keep them in check. Before the application of this specific it is, however, desirable to ascertain whether or not under certain conditions, such as the scarceness of Urosalpinx, the Natice may not develop a latent taste for young oysters. This precaution is the more necessary since in various standard natural history works small bivalve molluses are enumerated as constituting the ordinary food of the many species of the genus Natica.

Starfishes 
Starfishes of all descriptions, but more especially the ordinary five-fingered varieties, Asteridæ, are universally held up for condemnation as representing tho most insatiable foes of the oyster tribe. Whether this wholesale condemnation is a just one there are some reasons for doubting. In many instances it has been observed that the starfishes wero merely acting as scavengers, and preying on dead or dying bivalves. The direct experiment was carried out by nyself some vears since in one of the large English public aquaria of keeping oysters and starfish, including the accredited most aggressive species, Uraster rubens, in the same tank. These two pre-supposed antipathetic types were thus maintained side by side in perfect health for many months without a single instanco occurring of molestation of the oysters on the part of the starfish; these latter, however, fed freely on portions of the cut-up fish occasionally placed in the tanks. How far this vindication of the starfish's character would hold good in association with the common shore species of South Queensland has yet to be demonstrated, and in the interim it is desirablein the interests of the ofster-grower to recommend the clearance of this intruder as far as possible from off his beds or banks. In this connection a suggestion concerning the destruction of starfish may prove acceptable. It is by no means an uncommon practice among oyster cultivators on bringing up starfish in the dredge, or finding them on the banks, to rip them in pieces and cast them aside or into the water again under the impression that their life is destroyed. As a matter of fact each of the five finger-like processes separated from the starfishes' body is capable of growing into a fresh starfish, so that by the process of dismemberment the further multiplication of the species is accomplished. To encompass the certain destruction of these animals it is desirable that they should be carried to land and be deposited above the reach of the tide.

The different species of Sea Urchins, or Sea-Eggs, Echini, have been occasioually associated with oyster-eating proclivities. Their habits, however, are essentially herbivorous, and the only injury they might possibly, but very improbably, do to oysters is that of piercing the very young and fragile shells with their spines in passing over them.

Many varieties of fish prey more or less extensively, though not exclusively, on oysters. Among these may be mentioned the family of the toad-fishes, Tetradons, porcupine fish, Diodons, leather-jackets, MFonacanthi, and the several varieties of breams, Pagrido. The most destructive fishes ou the oyster banks are, however, undoubtedly the Sting-rays or" "Stingarees," as they are popularly denominated, belonging to the shark tribe and referable to the genus Trygon. The common dark brown species, Trygon pastinaca, is probably the greatest delinquent in this direction. It ajounds on the low-lying banks throughout the oyster-growing districts, and commits serious havoc among the young stock with the assistance of its parement-like crushing teeth. A more typical oyster-eating member of the shark tribe that abounds in the southern colonies and is occasionally taken in Moreton Bay is the so-called Port Jackson shark, Heterodontus Philippi. It is of a tawny brown colour with an abnormally large head and projecting brow ridges, and has a stroug sharp spine developed in front of each of the two dorsal fins. It rarely exceeds a length of 5 feet, but is provided with powerful crushing jaws, of greater strength even than those of the Rays, and with which it easily breaks up the largest oyster sbells. On certain of the Tasmanian oyster reserves and private beds it wrought such havoc that the oysters were ouly agved from entire destruction by fencing them round with wire netting. With reference to its oystereating proclivities, the species is known in Tasmanian waters by the name of the "oyster crusher," while in some parts of Victoria it is called the "pig-fish." By way of illustrating the peculiar hardness of its palate it may be mentioned that in the neighbourhood of Port Jackson, New South Wales, it feeds very extensively on the spine-covered Sea Urchins, Echini, its teeth being frequently stained a bright violet hue through its predilection for this diet.

A species of boring sponge, Hymeniacidon celata, has here, as in European waters, to be included among the enemies of the oyster. Its attacks are, horrever, confined almost exclusively to old shells in deep water, and which it honeycombs in every direstion. The parasito is soon got rid of by the exposure of the affected oysters to light and sunshine on the banks.

Several species of birds, including notably the so-called oyster-catcher, Hematopus longirostris, and the numerous members of the crane tribe that frequent the oyster banks at ebb-tide, prey to some oxtent on the young oyster brood. Next to the borer, however, the greatest amount of injury to the oyster cultivator's growing crops is probably committed by the innumerable species of crabs that infest the beds and banks.

A destructive agency that has caused great losses to the oyster-growers of New South Wales, and of which there was some suspicion of its having made its appearance among the oysters in Wide Bay, is what has been styled the "Worm Disease." This disease is characterised by the presence within the oyster shells of patches of mud, which are more or less completely covered in by a a shelly or membranous redeposit. One or more small worms, Leucodore ciliata, are almost invariably found enclosed within these mudcavities, and from which, through a tubular channel, they maintain a communication with the outer water. This worm is usually eredited with being the primary origin of the so-called disease, but on the strength of a slight passing acquaintance made with it in New South Wales, and all the facts relating to it that hare been published, I am inclined to believe that the organism is only an aceompaniment, and not the cause of the disease. Mr. Whitelegge, of the Sydney Museum, who has approached the subject from the standpoint of the worm being the originator of the disease, has made the following remarks, after making investigations concerning its occurrence at the Hawkesbury River :- "The principal home of the worm appears to be on the mud-flats about low water-mark. The oyster from this region, the Hawkesbury, were invariably infected with the worm, particularly those which lay loose on the surface or were partially buried in the mud. Those oysters which were fixed to some solid substance, and elevated ever so little above the surface of the mud, were comparatively free from the pest." The foregoing testimony goes far to show that this so-called worm disease is essentially a "dirt disease." It is only in a muddy environment, unsuitable for the healthy growth of the oyster, that it spreads, and that it is the mud, and not the oyster per se, that attracts the worm, is demonstrated by the fact attested-tbat the oysters elevated but a few inches above the muddy stratum are relatively free from the affection.

The inference that I am inclined to arrive at concerning the occurrence and manifestations of this disease, is that the oyster through the foulness of its surroundings absorbs within its shell cavity, by the ciliary action of its gills, a greater amount of mud than it can get rid of, and that the worm in its free-swimming embryonic state being drawn within this cavity by the same cilliary currents of the oyster, settles down with alacrity within so congenial a mud-lined cradle. The worm, Leucodore ciliata, under 
discussion, enjoys an almost cosmopolitan distribution. Its habitat, as described in Dr. Johnson's catalogue of non-parasitical worms in the year 1865, is as follows:- "Found living between seams of slaty rock near low-water mark, and burrowing in the fine soft mud which lines the fissures." By a wellknown Queensland oyster cultivator, I have been informed that the same species of worm was noticed by him many years ago burrowing in the mud-filled crevices of timber wor!s in Sydney Harbour. The species, like most members of its class, is an essential mud lover, and its natural instincts guide it in its earliest larval condition to seek out and establish itself within any appropriate mud-lined crevice.

So extensive have been the depredations of this mud disease with its associated worms in New South Wales, that many of the formerly most productive oyster grounds of that Colony have been practically depleted, and it is owing to this disease, mainly, that instead of exporting, that Colony is now so largely dependent on Queensland and New Zealand for its supplies. Much anxiety is naturally manifested to exclude this destructive agency from taking up its abode in Queensland waters, and haring that circumstance in view, the fullest information concerning its probable cause and possible prevention will doubtless prove acceptable. In this direction I herewith reproduce the views on this subject expressed in a lecture upon "Oysters and Orster Culture in Australia," I contributed to the meeting" of the Australian Association for the Advancement of Science held at Christchurch, New Zealand, in January last. After enumerating the more salient features of the disease as already described, I thus continue:-

"The rock oyster, Ostren glomerata, affected by the disease is, as previously remarked, a species that attains to its maximum development in brackish water, and indeed survives exposure to fresh water immersions in times of floods that would prove fatal to the so-called mud oyster, Ostrea edulis. $\Lambda \mathrm{s}$ a corollary to these brackish water proclivities of Ostrea glomerata, its most Iuxurious development in New South Wales has been high up the riverine estuaries that so abundantly intersect the coast line. The Hunter, the Hawkesbury, and the Clarenee rivers may be mentioned, not only is the most important of the oyster-growing areas, but atso as those in which the worm disease, or, as 14 may be more correctly termed, the 'mud disease,' has been most prevalent. In my opinion it is the alter ed conditions of these rivers, brought about mainly through human ageney, that has induced the diseased condition of the oysters, their waters, in fact, being rendered more or less incapable of supporting the molluse in a healthy state.

"Through the clearance of the land and the establishment of townships and settlements throughout the watersheds of these rivers, the rainfall which in former days fell upon and was more completely absorbed by the primeval forests is now carried quickly away, and emptied by drains and culverts into the watercourses communicating with the rivers. Simultaneously with this augmented discharge of water into the rivers a vastly larger quantity of sediment is brought down, accompanied by a considerable percentage of organic and chemical pollution that had no place in the composition of the water under those conditions in which the oysters originally grew and flourished. This greatly aurmented accession of flood water, with its accompauiment of sediment and chemical pollution, cannot exert other than a very deleterious influence upon the riverine oyster fisheries.

"A case in point in which the oysters, formerly growing abundantly many miles up a river's course, have been gradually pushed further and further down towards the sea through the agencies just described fell under my personal observation in Tasmania. In the river Tamar, debouching on the northern coastline of that colony, the mud oyster, Ostrea edulis, was originally abundant from the Heads half-way to the town of Launceston, some forty miles distant. By degrees, as borne testimony to by residents of the district, the oysters have gradually disappeared from the formerly prolific higher portions of that river known as Whirlpool Reach and the Middle and Eastern Arms. On my first visit to the Tamar estuary a few oysters were still left in the lowest bay known as the West Arm, but these, both young nnd old, were in a dead or dying state, owing chiefly to prolonged immersion in water containing an insufficient amount of saline ingredients, but organic pollution from the town of Launceston probably also playing an important part in their destruction. Within a few years after this first visit oysters were practically extinct in the Western Arm, and no success attended the efforts made to resuscitate the fishery in that district by artificial culture. The last lingering remnant gathered there were in a decidedly unhealthy state, the shells being discoloured and wanting in solidity, and the contained oysters being in the poorest possible condition.

"Should the interpretation here suggested be correct with relation to the diseased condition of the New South Wales Oyster Fisheries, it is evident that the prospects are but small of recovering the ground lost to oyster culture in the several districts affected. It will consequently be incumbent on the oyster growers of that colony to make the most of the water area left to them where the water is pure and not liable to be invaded by the disease, and, if they are ambitious to regain that position formerly held in which the colony was indepondent of supplies from external sources, they will require to turn their attention to the culture of the molluse on a far more scientific basis than has been hitherto attempted in New South Wales waters."

Respecting the existing or prospective invasion of the Queensland oyster-beds by this mud disease, with its accompanying parasitic worms, $I$ am pleased to be in a position to report that there is, at all events, no evidence to hand of its presence at the present time. A little while since there was some suspicion of its having made its appearance in Wide Bay, and a few specimens of oysters which, on being opened, were found to contain a parasitic worm, were submitted for my examination. The worm, however, in these solitary instances, was a nereid representing a different geuus than that associated with the New South Wales disease, and had apparently gained access to the shell through a perforation originally made by a boring whelk. There are circumstances, in my opinion, which will operate for a long while, and. it is to be trusted, permanently, against the introduction of the disease under notice into Queensland waters. In New South Wales, as previously stated, the oyster fisheries devastated belong entirely to riverine systems that have become much altered in character, and polluted by sedimentary deposits through the clearance of their inland watersheds. The oyster grounds of Moreton and Wide Bays; on the other hand, have such near and free communication with the open ocenn that they are not influenced to anything approaching the same extent by floods from the tributary rivers, and from the effects of which they speedily recover, 
It appears desirable for me to montion here that the fears that have been expressed in somo quarters lest the disease under notice should be introduced with the worm from New South Wales are, in my opinion, altogether groundless. As a matter of fact Lencodore is already here; it is of cosmopolitan distribution, and has been obtained by me among the coral reefs as far nortir as Torres Straits. So long as the orster banks of Queenslnnd are maintained in a clean and healthy state, the worm is not likely to invade them. So soon, however, as these become choked with foul mud and sedimentary deposits, the conditions will be made favourable for the advent of the worm, and it may most assuredly be expected. While thus enjoying present immunity from the worm disease, which has wrought so much havoc to the oyster fisheries of a neighbouring colony, there are circumstances, subject to the control of human agency, which might arise and exert a very serious if not quite as disastrous an influence as those of Moreton Bay. Reference is here made to the effects that would probably ensue through the establishment on the Brisbane or other tributary rivers, on an extensive scale, of chemical works or factories without restrictions being placed on the discharce into their waters of noxious fluids or other deleterious matters. At present but a few of such factories exist, and comparatively little harm is caused, though already the destruction of fish through such polluting agencies is now and again reported With a multiplication of such pollution-creating factories, there can be no doubt that the effects would be serious to both the ovster and the general fisheries of Moreton Bay, and so many and valuable interests being bound up in these industries, it is highly desirable that measures should be taken in time to safeguard them from all risk of deterioration through such an easily preventable cause.

There is one other agency at work which, if allowed to continue unchecked, threatens to exert an unfavourable influence on the ofster fisheries of Queensland. Under existing regulations what are known as the Goverument or public oyster reserves are supposed to be retained as breeding centres for the express benefit of the general public, who are permitted to help themselves without restriction to such oysters as they can consume on the ground, but are prohibited from carrying them away. This privilege, however, has been abuser to such an extent, that on many of the most extensive of these reserves the oysters have been completely stripped and carried off in a wholesale manner. It is, in my opinion, essential for the continued prosperity of the Oyster Fisheries of this Colony that judiciously selected areas should be strictly and permanently reserved as nursery or breeding centres for keeping up the supply of spat. Having regard also to the extent that many of the leased grounds and banks are denuded of their oyster crops without compunction or consideration for future cultivators, it is, I consider, highly desirable that a clause should be included in the leases granted requiring the continual reservation on the ground or bank of a certain proportion of breeding oysters or, at all events, prohibiting their entire removal. With such suggested breeding reserves, efficiently maintained, the Queensland Oyster Fisheries would be well insured against all risk of the injury through over-depletion that bas befallen those of certain of the more Southern colonies. At the same time, the foundation would be laid for the development of this important industry on a more extensive scale than has hitherto been attempted, and for which there is a wide field open, more particularly in the direction of eanning and other preservative processes for the export market.

\section{THE EMBRYOLOGICAL PHENOMENA OF THE QUENSLAND COMMERCIAL OYSTER. (Ostrea glomerata)}

Considerable uncertainty having up to a recent date prevailed concerning the embryological phenomena of the ordinary rock oyster of Queensland and New South Wales, I devoted some time last year to the investigation of this subject. The results of these investigations rere embodied in a paper communicated by mo to the Royal Society of Qucensland in February of that year, and from which the following account has been epitomised:-

"The researches that have been already conducted by European and American naturalists, with relation to the commercial oysters of the Northern hemisphere, have elicited the fact that the fertilisation and development of the oyster brood or spat is formulated on two essentially distinct plans. In the case of the most familiar Luropean type, Ostrea edulis, represented by the far-famed British native and the variety so extensively cultivated on the coast of France, the propagation of the species is accompanied by a condition in which the orster is unfit for consumption, and is prohibited to be sold. This is occasioned through the circumstance that the parent oyster nurses or incubates its brood within the pallial or mantle cavity, throughout the early stages of its development, and does not liberate it until the shells of the young oysters are fully formed. An oyster eaten during the later phases of the breeding season appears to be full of sand or grit, this being due to the presence of the many millions of minute embryonic shells. By oyster dealers at home, two distinct spawning conditions of the oyster are recognised: the one, when the embryos contained within the mantle chambers of the parent are white and colourless, being devoid of shells, is designated the "white sickness." The later stage, when, the shells being formed, a grey or blackish tint is imparted to the entire mass, is known as the "black sickness.' The close or spawning scitson of the ordinary European oyster, Ostrea edulis, extends throughout the summer, from May to September, and is popularly defined as represented by those months in which the letter ' $r$ ' is absent.

"The fecundation of the ova of the European oyster necessarily takes places within the mantlecarity or brood-chambers of the fernale, the fertilising fluid or milt of the male being discharged into the water, and from thence it is absorbed and brought into contact with the mature ora by the ciliary currents that exercise the ordinary respiratory and food-purveying functions in the female mollusc. This plan of propagation was until within recent years supposed to apply to all descriptions of oysters. Investigations associnted with the reproductive phenomena of the American commercial oyster, Ustrea virgineana, failed, however, to discover any trace of the brood or spat within the mantle cavities of tho breeding oyster, and it was ultimately demonstrated by Dr. Brooks (1880) that both the ova and milt were simultaneously discharged into the water in their mature condition, and fertilisation being there effected, the entire derelopment of tho embryo took place independently of the parent. Such being the case, the artificial propagation of the species by the commingling in sea water of the matured sexual elements was considered fersible, and was successfully accomplished by the above-named authority. In the case of the typical European oyster, Ostrea edulis, such a method of artificial propagation is not 
possible, chiefly on account of the fact that the embryos are matured within the brood-chambers of the parent in a flud rnedium, containing a large proportion of albuminous matter that cannot be artificially produced. Following upon the discovery of Dr. Brooks in connection with the American oyster, it was demonstrated by M. Bouchon-Brandeley, in tho year 1882, that the small Postuguese oyster, Ostrea angulata, exhibited developmental phenomena which coincided essentially with those of the American species, the ora being similarly discharged into the water, where they are fertilised and developed independently of the parent. The artificial fertilisation of the ova of this species, and the investigation of the more important embryological phases of this Portuguese type, were also successfully carried out by the authority cited.

"The oysters of Australia, like those of the Northern hemisphere, exhibit two distinct plans of propagation. The commercial form indigenous to Tasmania and Victoria, but now so reduced in numbers by exhaustive fishing as to be scarcely known in the market, cannot be distinguished from the Ostrea edulis of European waters, and is usually associated by naturalists with the same specific title, but is sometimes denominated the variety Angasi of the same type. The reproductive phenomena of this oyster have been personally investigated by myself, and were found to coincide precisely with those of its European congener, the embryos in like manner being fertilised and developed within the mantle or pallial cavities of tho parent. similar phenomena have also been found by me to obtain in association with the closely allied New Zealand unud oyster, and which is also apparently a local variety only of the sane species.

"The most important commercial oyster of Australia is undoubtedly the familiar rock oyster, Ostrea glomerata, of which Qucensland enjoys the enviable position of producing the largest supplies; Moreton Bay and Wide Bay alone growing sufficient quantities not only for home consumption but also for exportation to the neighbouring colonies. The method of propagation of this oyster, to which $I$ have paid some attention within the past few weeks, is, I find, in all respects, identical with that of the American commercial species, Ostrea virgineana. The fertilisation of the ova is brought about by their coming in contact with the milt or sperm cells in the open water, the young embryos being thus cast adrift and thrown upon their own resources from the earliest period of their existence. The artificial propagation of this species by the abstraction of the matured sexual elements, the ova and spermatozoa, and their admisture in a little sea water, may in consequence be eas'ly effected, and yields a most interesting and instructive embryological study. The method of procedure successfully adopted in accomplishing such artificial propagation, and the more conspicuous metamorphoses through which the embryo passes before assuming the parent form, may be described as follows:-

"The aid of a microscope with a magnifying power of about 200 diameters is, in the first instance, indispensable for securing the most satisfactory results. On opening a number of oysters, the creamcoloured fat-like mass near the hiuge or joint of the bivalre shell represents the seat of the reproductive elements. Inserting a fine spatula in the midst of this mass a small portion may be abstracted, and spread out in a drop of sea water, or the natural juices of the mollusc, on an ordinary glass slip. Placed under the microscope, the ova or germs of the female oyster will be at once recognised by their ovate or prriform contour, the separate ova having an arerage dianeter of the $\frac{1}{60} \overline{0}$ th part of an inch. The male elements or spermatozoa, when abstracted and similarly treated, present a widely different aspect. Its separate elements are so diminutive as to appear as minute granules only under the same magnification, and a considerably higher amplification is requisite to illustrate their individual structure. This is then shown to consist of a minute bulbous head and an exceedingly slender flexible hair-like tail, the pro. portions between the two being much the same as that of the head and shank of an ordinary pin. After a little experience it will be found easy to distinguish the comparatively coarse granular ova from the cloudy masses of spermatozoa, when placed on the glass slip, with the aid only of an ordinary pocket lens or even the unassisted vision. The assistance of the microscope is, however, desirable to insure the most favourable results, and is altogether indispensable for tracing the further development of tho embroyos. In many instances it will be found, what can be recognized only with the microsope, that the ova or spermatozoa, are not sufficiently matured, or, in the case of oysters purchased in the market, have become deteriorated by isolation from their native element for too long a period to permit of perfect fertilisation. All conditions being satisfactory, the ova under the microscope should present a clean and evenly rounded outline, while the vitality of the spermatozoa should be manifested by their active oscillating and vibratory movements. Should the sperm cells fail to exhibit this ritality, their admixture with the ova will prove of no avail.

In practice it will be found that the number of oysters containing the female elements or ova is greatly in excess of those producing the milt or sperm cells, the average proportion associated with many hundred examples recently examined being one male to sis or seren females. The small quantity of milt that is required to fertilise a very large number of ova satisfactorily explains Nature's economy in this direction. No peculiarities of external structure exist, so far as I have been able to ascertain, that permit of distinguishing between the male and female oyster before it is opened. Healthily matured milt and ora having been successfully obtained, portions of each, the ova predominating, may be mixed in a watch-glass half full of sea water, and well stirred togother. The ova, being heavier, will soon sink to the bottom, leaving the spermatozoa diffused as a cloud through the water. After an interval of ten minutes the top water may be poured off or withdrawn with a pipette and fresh supplied, and any fragments of lacerated tissue or tufts of immature milt be removed with a needle; these, if loft, will decay and pollute the water. The pouring-off process should be repeated until the top water is quito clear and the bottom consists entirely of fertilised ova. If a small drop of water containing the mingled milt and ova is examined under the microscope at short intervals, some remarkablo changes in the form and structure of the ora will soon be observed.

Almost immediately following upon the admixture of the two elements it will be found that the sperm cells are adhering in numbers by their dilated heads to the delicate capsular investments or vitelline membranes of the ova, and communicating to many of them, through the vigrous vibrations of their tail-like prolongations, a distinct oscillatory motion. It may also be observed that through the aperture of the narrower end of the capsule, known as the micropyle, several of the sperm cells have effected an entrance, and have been brought into direct contact with the body of the ovum. The fusion betreen the two elements that then takes place is not casy to trace, but the results arising from the union are speedily manifested. The orum prior to fertilisation was distinguished by tho prescnce of a central clear area with a contained nodular structure, the two represcnting what aro distinguished technically 
technically by the titles of the "germinal vesicle" and "germinal spot" or the "nuclcus" and "nucleolus." Shortly after fertilisation the substance of the orum becomes opaquely granular throughout, and the germinal vesicle is no longer risible. Within the second hour a suall globular protuberinco will have made its appearance at the broader end of the ovum, and opposite to the micropyle. This is the so-called directive or polar cell. Quickly following upon this, the cntire body-mass of the orum becomes furrowed or constricted across the centre, anil cach half is secn to contain a central nucleus. The upper half, associated with the polar cell, now divides itself into two equal parts. These again split into four and next into eight, the aspect of the orum or embryo, as it may now be correctly termed, at about tho end of the third hour being that of a number of small coherent cells, superimposed symmetrically on the top of a large basal cell.

This condition of development represents an important phase in the life history of the embryo oyster. There are now present all the essential elements out of which the perfect animal will be built up. Out of the smaller superincumbent cells all the investing membranes, tactile organs, and essential animal structures will be fashioned, and thoy are consequently distinguished as the formative cells. The larger basal cell, on the other hand, represents the nutritive or regetable element, ont of which will be constructed the stomach, alimentary track, and all the appended viscera. Within from four to six hours the smaller or formative cells hare so increased and spread as to completely enclose the large nutritive cell, and which in its turn now divides up and lays the foundation of the alimentary track. Fine hairlike cilia are at this stage developed upon the external surface of the embryo, and by means of which it progresses through the water in an irregular rotatory manner. 'The polar cell, which up to this stage had occupied a conspicuous position, now breaks loose and disappears. The metamorphoses from this point progress more slowly. From the tenth to about the fifteenth hour the general shape of the embryo is somewhat kidney or turban shaped, it haring a slight dejression on one side. This represents what is known to biologists as the gastrula stage, a struetural phase which has been found to be common to some period in the derelopment history of almost every known form of animal life higher than the unicellular protozoa. In its most typical condition this gastrula embryo consists of a cup-shaped body composed of two single cell layers, the outer being built up of the animal or formative cells, and the inner one out of the nutritive or vegetable cells. 'The distinctivo appellations of the "epiblast" and "hypoblast" are more commonly applied by biologists to these respective outer and inzer cell layers.

After passing the "gastrula" stage, development towards the typical organisation of the parent oyster proceeds apace. The central cavity representing the stomach opens out by an anterior and a posterior passage and apertures, which correspond respectively with the throat and mouth, and the intestine and vent. The shells make their appearance at a depression in the dorsal surface, and gradually increase in size until they enclose the entire body. Simultaneously with these metamorphoses a dise covered with powerful vibratile eilia has developed at the anterior extremity, and with the assistance of which the embryo oyster can propel itself rirorously through the water. As the shells grow larger and heavier the little oyster becomes less capable of sustaining itself in the water, and finally sinks to the bottom. This is a crucial peoch in the mollusc's existence. Should it settle upon a rock, shell, or other clean, hard substance, it attaches itself to it, and its life is assured; but should it, on the contrary, light upon soft mud, sand, or other material to which it cannot adhere, it inevitably perishes. The proportion of young oysters that find a secure anchorage in comparison with the vast numbers that are devoured, or become literally lost at sea, is necessarily infinitesimal.

The time taken by the embryo of the Australian oyster to pass through the series of metamorphoses enumerated, and to arrive at the attached or sedentary state, has been found by me, under favourable conditions, to arerage four days, two out of these elapsing before the shells become conspicuously apparent.

Within from eighteen months to three years from the date of its birth the embryo becomes a marketable oyster measuring the standard two inches in its longest diameter. Such, howerer, is the precocity of the species that, oyster brood not more than three months old, and but half an inch in diameter was found, in association with the foregoing embryological inrestigations, to be laden with fully-matured ova and milt.

Drawings made with the aid of the microscope of all the leading developmental phases of Ostrea glomerata, as described in the foregoing communication, are reproduced in Plate IX of this report. Some further experiments that were conducted in association with these embryological investigations with the object of ascertaining the influence of water of varying density, as in time of floods, upon this embryonic oyster brood have been referred to at page 7 . Amoug the practical results suggested in connection with the foregoing embryological data here recorded, is the feasibility of fertilising and artificially propagating the embryos of Ostrea glomerata in numbers largely in excess of what is accomplished in a state of nature. In Europe, where the demand is so much in excess of the supply, and the market prices consequently higher, and also in America, much attention is being given to the problem of thus successfully cultivating oysters from their earliest embryonic state. By such time as this supply and demand shall be equivalently balaneed in the Australian market, a resort to this supplementary method of artificial fertilisation and propagation may be found profitable.

\section{Detatls of areas Regerted or Leased for Orster Culdure is Queenseavd Waters, witi} Return of Quantities and Value of Oysters Exported.

The areas devoted to the industry of oyster culture in Queensland waters fall under the three separate categorics of dredge sections, orster banks, and oyster grounds. Under the first-named title are included extensive water areas producing dredge oysters only, and not extending shorewards abore the limit of low-water mark. These areas are leased by auction for terms of fourteen years to the highest bidder. The waters of Moreton Bay were originally subdivided into forty-two such sections. The ralue of certain of the more productive of these sections may be gauged by the fact that the rental realised for one of the more important unes when recently put up to public auction was no less than $£ 1,000$ per annum. Within the term of "oyster banks" are included all oyster-bearing banks, reefs, or other areas comprised within the limits of high water-mark and two feet below the lowest ebb. For these areas licenses are issued at the uniform rate of $£ 5$ for any such bank not exceeding 30 acres in extent. The total number of banks marked off, according to the latest returns, included in MIoreton Bay, is 347 , and in Wide Bay 167. In the Rockhampton district, including Rodd Harbour, Port Curtis, and Keppel Bay, between 
forty and fifty similar banks have been licensed or are under survey. The subdivisions termed "oyster grounds" have been recently defined to take the place of "dredgo sections," and for the purpose of including areas producing oysters in collectively deep or shallow water, or from high-water mark on one side to the same limit on the opposite side of any given area. These oyster grounds are, as in the case of the dredge sections, let by auction on leases of fourteen years' duration to the highest bidder.

The license-fees payable upon the boats occupied in the oyster trade, as affixed by the Oyster Act of the year 1886, is as follows :- $£ 1$ annually for every boat so employed that does not exceed three tons, and a further sum of 10s. for every ton or part of a ton above the measurement. The license-fee charged for every person engaged as master, servant, or assistant in dredging, collecting, ol carrying away oysters for sale, is $10 \mathrm{~s}$. per annum.

Return relative to the Quantity and Valde of Orsters Exported from Brisbane and MLarborough. BRTSBANE.

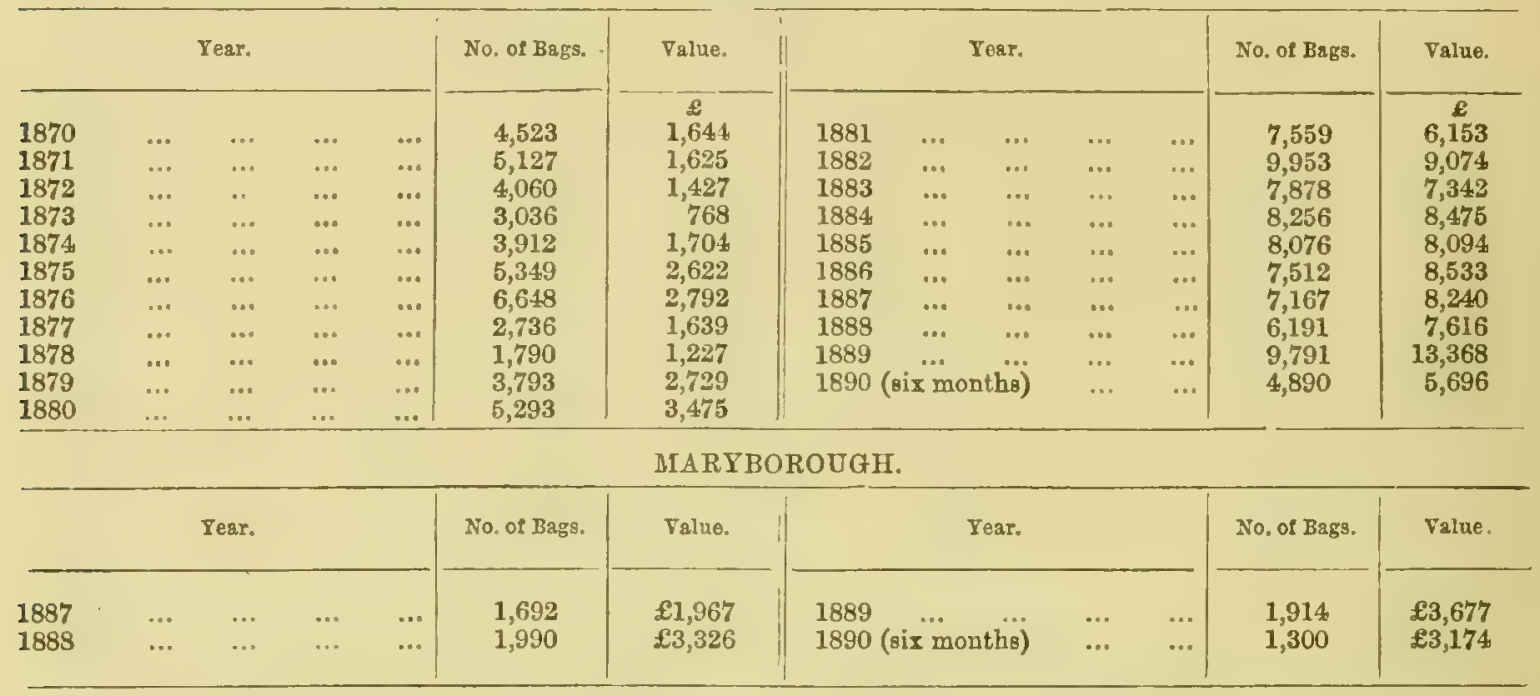

The foregoing return showing the quantities and value of the oysters exported from Moreton and Wide Bays, has been reproduced from the Inspector of Oyster Fisheries, Moreton Bay district (Mr. C. L. Fison), report for the year 1890. The figures relating to the Brisbane exports, extending over a period of twenty years, furnish a practical illustration of the steadily increasing value and extent of this highly important fishery.

It affords me much pleasure, in conclusion, to testify to the valuable facilities and assistance afforded me, whenever needed, by the harbour masters and fisheries inspectors of the various districts visited, towards the acquisition of the materials and information utilised in the compilation of this report.

\section{I have, \&c.}

W. SAVILLE-KENT, F.L.S., F.Z.S., \&c. Commissioner of Fisheries, Queensland.

\section{FXPLANATION OF PLATES I. TO IX., ILLUSTRATING QUEENSLAND OYSTERS AND OYSTER CULTURE}

\section{Plate I.}

Figure 1.-Typical cluster of the ordinary commercial oyster, Ostrea glomerata, the largest shell exposed to view, showing at the point $a$, a circular hole made by the boring whelk, Urosalpinx paivoe. glomerata.

Figures 2 and 3.--Right and left, or attached and opercular valves, of the ordinary growth of Ostrea

Figures 4 and 5.-Adult shells and young brood of the elongate variety of Ostrea glomerata, of common occurrence in deep water.

Figues 6 and 7.-Vertical and lateral views of the orbicular variety of Ostrea glomerata, most abundant in the Northern districts.

Figure 8.-Oyster whelk, Potamides ebeninus, with attached oyster brood.

Figure 9.-Oyster spat and brood from one to threo or four weeks old, in its earliest condition of attachment to the cemented collectors figured at Plate VIII.

Figures 10 and 11.-Dorsal and ventral aspects of the oyster-boring whelk, Urosalpinx paiva.

Figure 12.-Spinous oyster, Ostrea spinosa. A small non-commercial species from Keppel Bay. Grows to about twice the size of the illustration.

Plate II.

Figure 1. - Lateral aspect of typical example of the coral rock oyster, Ostrea mordnx, attached to fragment of coral from the Capricorn Islands, Great Barrier system, Lat. $23 \frac{1}{2} \mathrm{deg}$.

Figure 2.-Vertical view of common modification of Ostrea mordax, in which the anterior or butt end of the left or attached valve is produced into a hollow beak; a variety apparently identical with the Ostrea cucullata, of Born.

Figures 3 and 4.-Attached and opercular valves of the beaked variety of Ostrea mordax, the black scar of attachment of the adductor muscle being conspicuously developed on the opercular valve.

Figure 5.-A cluster of the non-cominercial oyster, Ostrea crenulifera.

Figures 6 and 7:-Dextral and ventral aspects of a detached example of the same species.

Figure 8.-Lower or attached valve of the poisonous oyster, Spondylus $8 p$. 
Puate III.

Figure 1.-Lateral viow of complete specimen overlying interior face of single-attached valve of the black-bordered oyster, Ostrea nigro-marginata, from Adolphus Island, Torres Straits.

Figure 2.- Marginal view of complete example overlying interior faco of attached valvo of the coxcomb oyster, Ostrea cristi-galli. From 11 Island, off Mackay.

Figures 3 and 4.--Ventral and dorsal views of the "borer"-destroying whelk, Natica plumbea.

\section{Piate IV.}

Figure 1.-Boat-shaped example of black-bordered Oyster, Ostrea nigro-marginata.

Figure 2.- Tubular oyster, Ostrea cornucopice, showing at $h$ the hinge, and at $h^{1}$ the path of growth up which the hinge has gradually travelled with the increasing size of the shell.

Figure 3.-Example of Ostrea cornucopio, showing the hinge path $h^{2}$ moro conspicuously.

Figure 4.-Diagrammatic view of Ostrea cornucopia, showing at $a$ the points of attachment of the adductor muscle, and by the clear space the dimensions of the internal cavity.

Figure 5.-The saddle oyster, Ostrea sellaformis, intemal view of a single valve.

Figure 6.-Lateral aspect of the component valves of Ostrea sellaformis, showing their characteristic indentation.

\section{Plate V.}

Figure 1.-A typical cultivated oyster bank, in Bribie Passage, Moreton Bay. From a photograph.

Figure 2.-An undisturbed or virgin oyster reef, in the "Narrows," between Port Curtis and Keppel Bay. A portion towards the centre of this reef having been undermined by the action of the water, has partly fallen away, exhibiting the density of the oyster stratum. From a photograph.

\section{Piate VI.}

Figure 1.-A mangrove oyster bank in its initial condition, with oysters, Ostrea glomerata, attached to the exposed roots and ventilating shoots or "cobbler's pegs" of the white mangrove, Avicennia officinalis. Reproduced from a photograph from Moreton Island, Moreton Bay.

Figure 2.-Mangrove oysters, Ostrea glomerata, attached to the elevated branching roots of the Orange Mangrove, Rhizophora mucronata. Reproduced from a photograph taken in the estuary of the Endeavour river, near Cooktown.

\section{Plate VII.}

Figure 1.-Typical rock oysters, Ostrea glomerata, growing on rocky boulders at the mouth of Tullebudgera Creek, Burleigh Heads, near Southport. From a photograph.

Figure 2.-A remarkably luxuriant mangrove oyster bank, consisting of solid masses of oysters, that originated from individuals attached to the roots and " cobbler's pegs" of the White Mangrove, as illustrated in Plate V., Fig. 1. From a photograph taken at Mangrove Island, Keppel Bay.

\section{Plate VIII.}

Oyster spat collectors constructed of "split palings" weighted with bricks and coated on the under surface with cement. The top figure gives a lateral view of a simply cemented collector, and the four lower figures the upturned surfaces of four collectors encrusted with oyster brood after remaining in the water about four months.

\section{Plate IX.}

Illustrating the Embrology of the Queensland Commercial Oyster, Ostrea glomerata-Gould.

Figures 1 and 2.-Unfertilised ova, with investing vitelline membrane and micropyle $(a)$ magnified about 500 diameters.

Figure 3.-Milt or sperm cells.

Figure 4.-Ovum with attached sperm cells immediately preceding amalgamation and fertilisation.

Figure 5.-Fertilised ovum from first to second hour after fertilisation. fertilisation.

Figuress 6 to 10.-Consecutive metamorphoses observable within the second and third hours after

Figures 11 to 13.-Changes progressing within the fourth to eighth hours after fertilisation. terminating in the ejection of the polar cell, and the complete investment of the larger nutritive cells or hypoblast, by the formative cells or epiblast.

Figures 14 to 16.-Phases of the embryo known as the "Gastrula" type, observed between the tenth and fifteenth hours of development.

Figures 17 and 18.-Phases arrived at from within twenty-four to forty hours, and in which the shells $(s h$.$) , mouth \left(m_{.}\right)$, and vent, $(v$.$) , of the perfect oyster have made their appearance.$

Figures 19 and 20.- Lateral and dorsal aspects of embryo three to four days old, and in which the shells have grown to such dimensions that they entirely enclose the body when contracted; magnified about 200 diameters.

Figure 21.-Earliest observed attached condition of the oyster embryos or "psat." Attained to within the fourth or fifth day succeeding primary fertilisation of the ovum; magnified about fifty diameters. 



\section{Plate I}
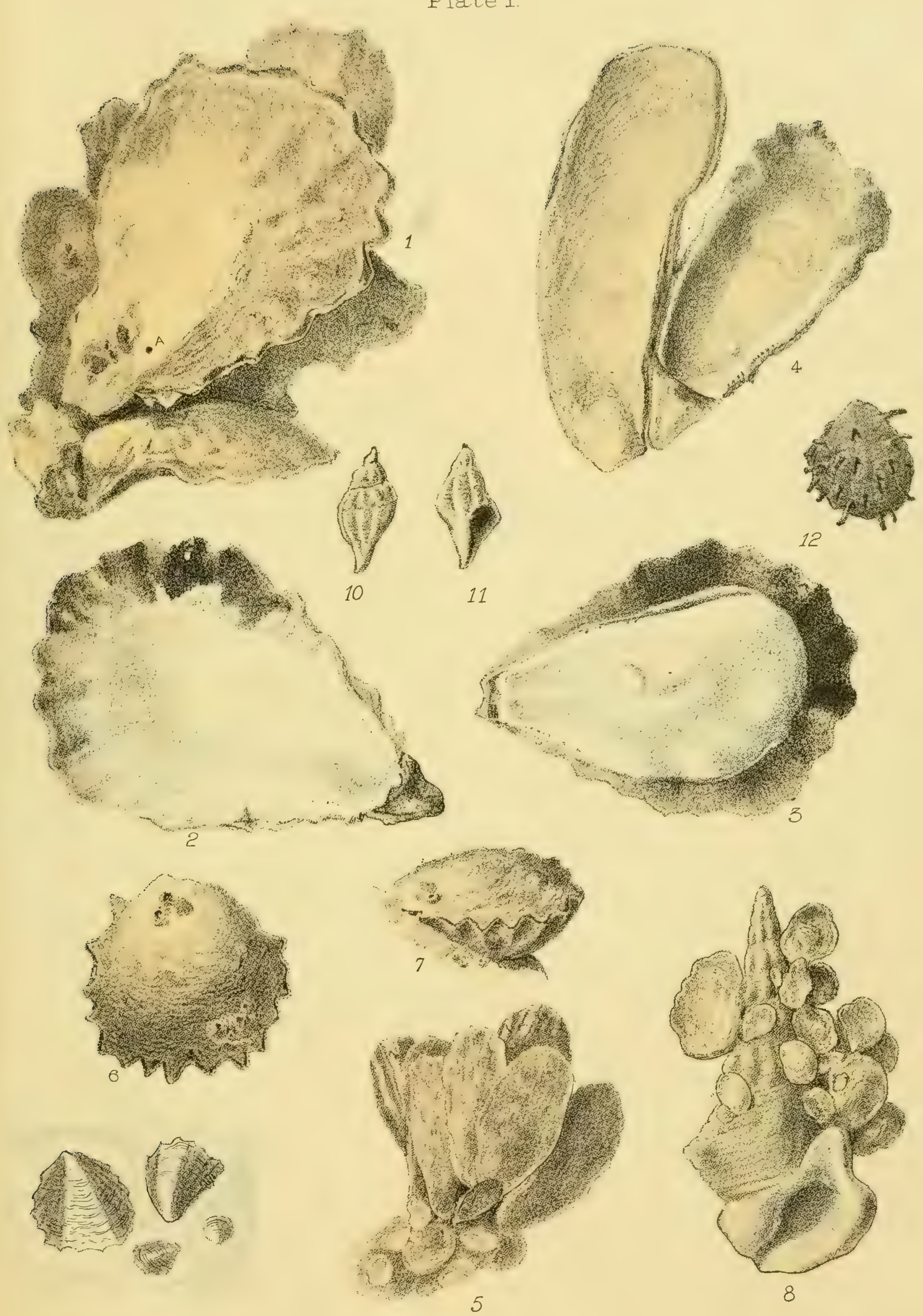

8 


Plate III.

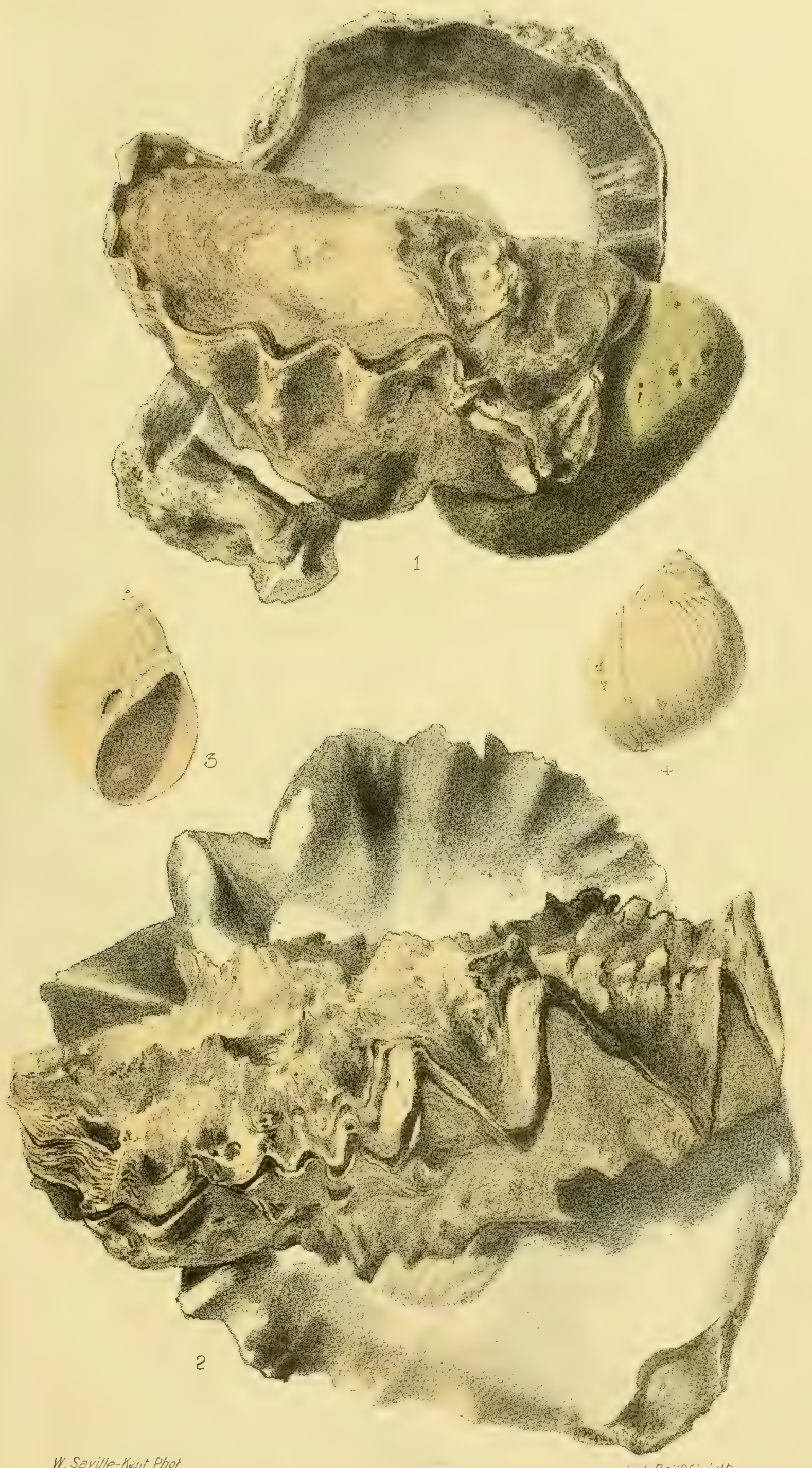





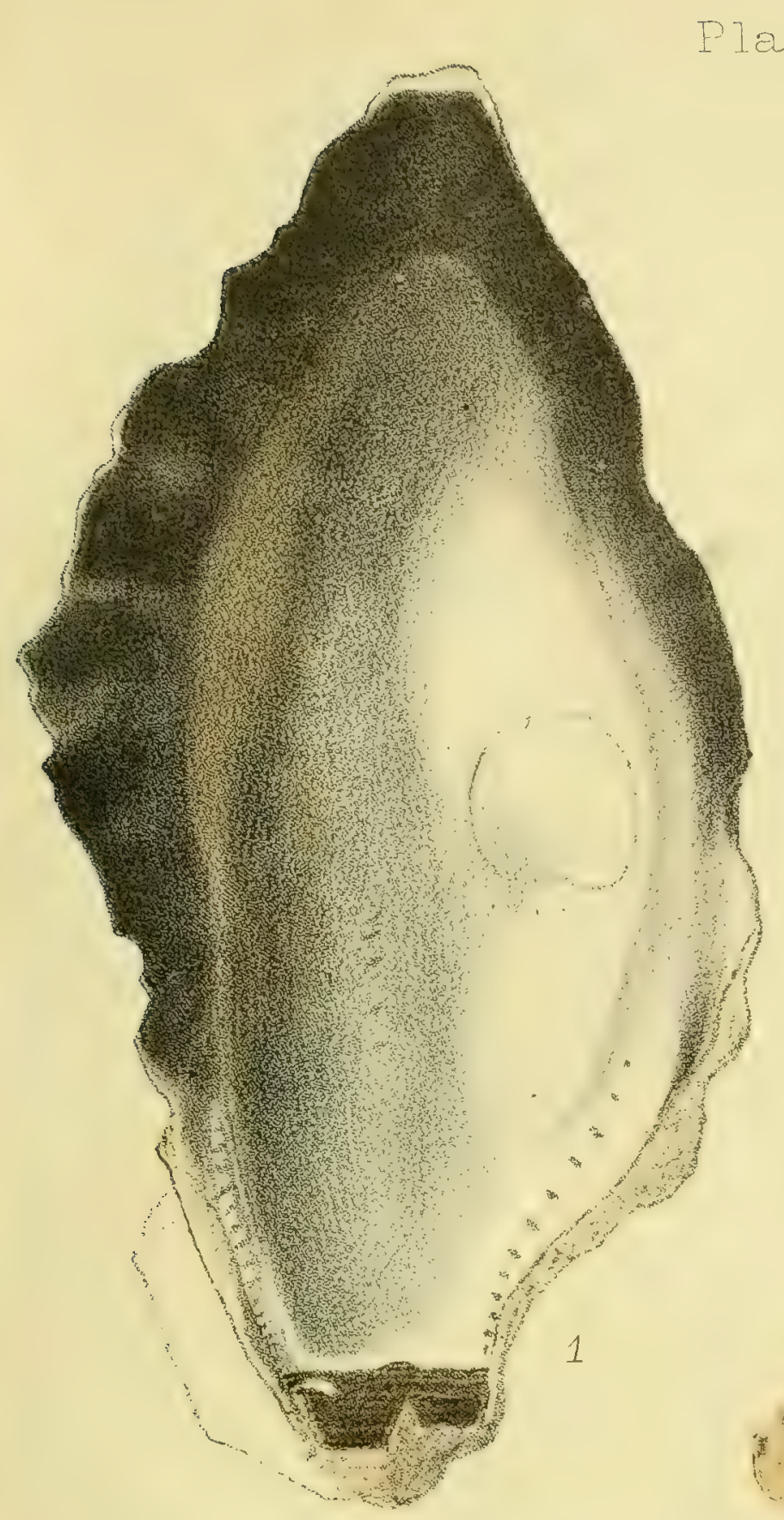

late IV.
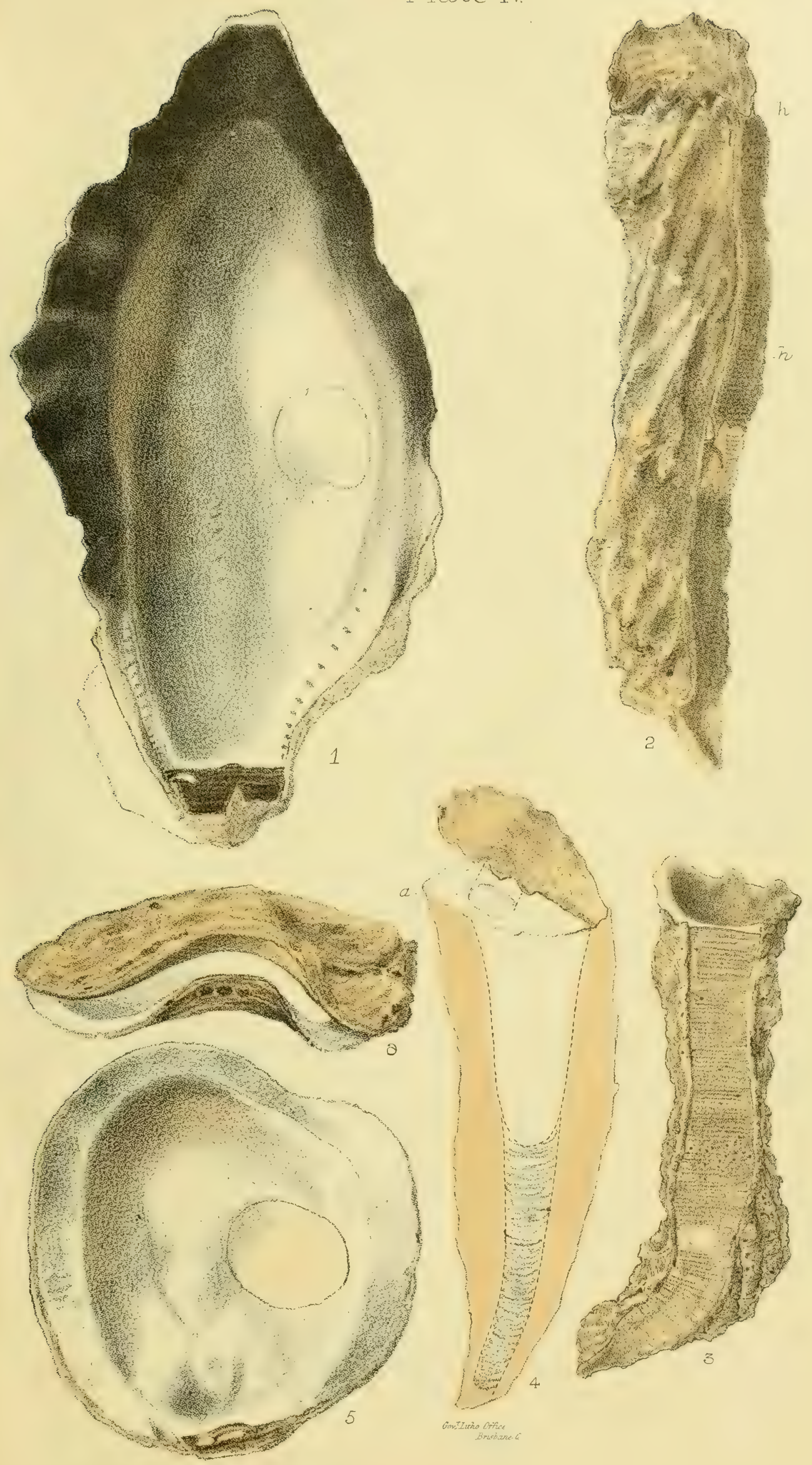



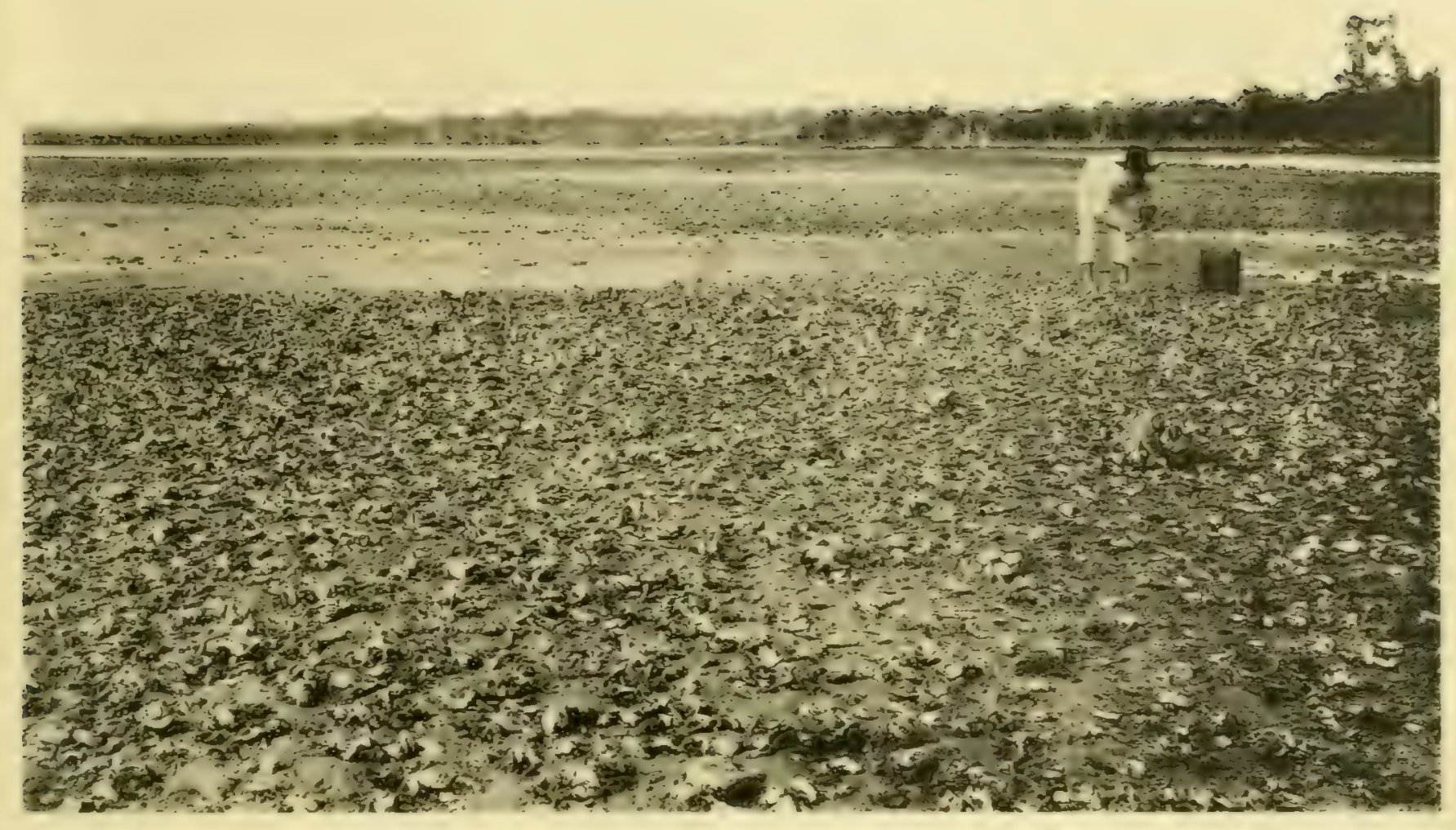
Fig. 1
CULTIVATED
OYSTER
EANK MORETDN BAY

1.0.
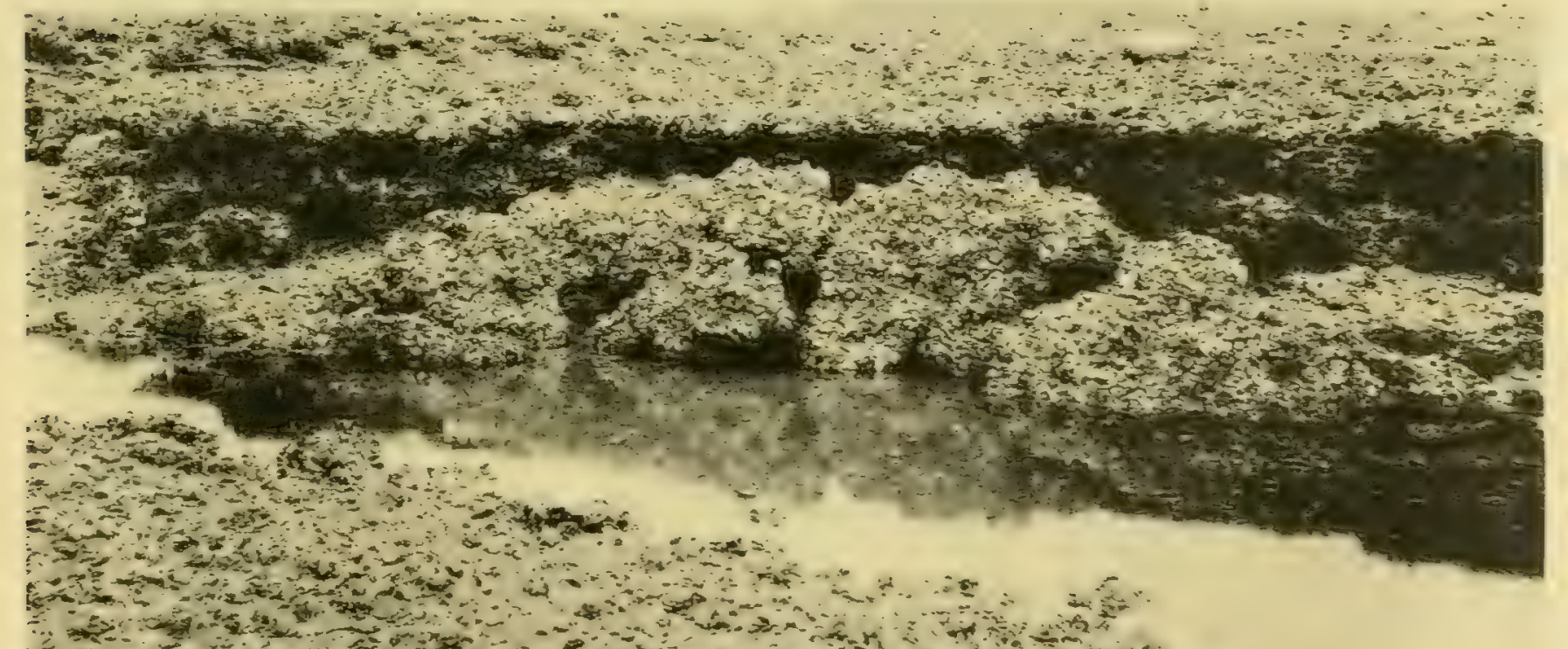

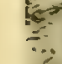





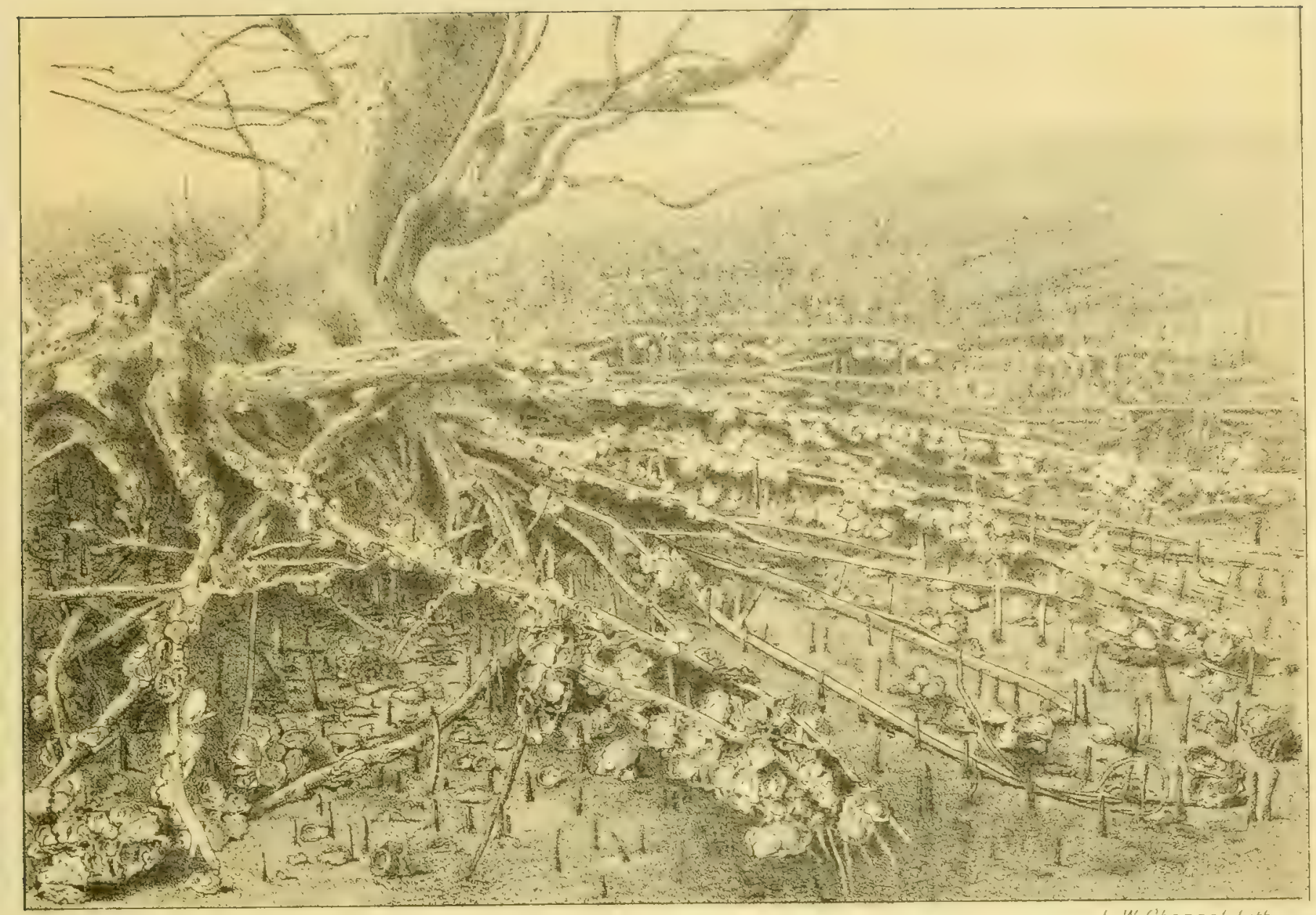

Mangrove Oysters Moreton Bay

MANCROVE OYSTERS. GOOKTOWN

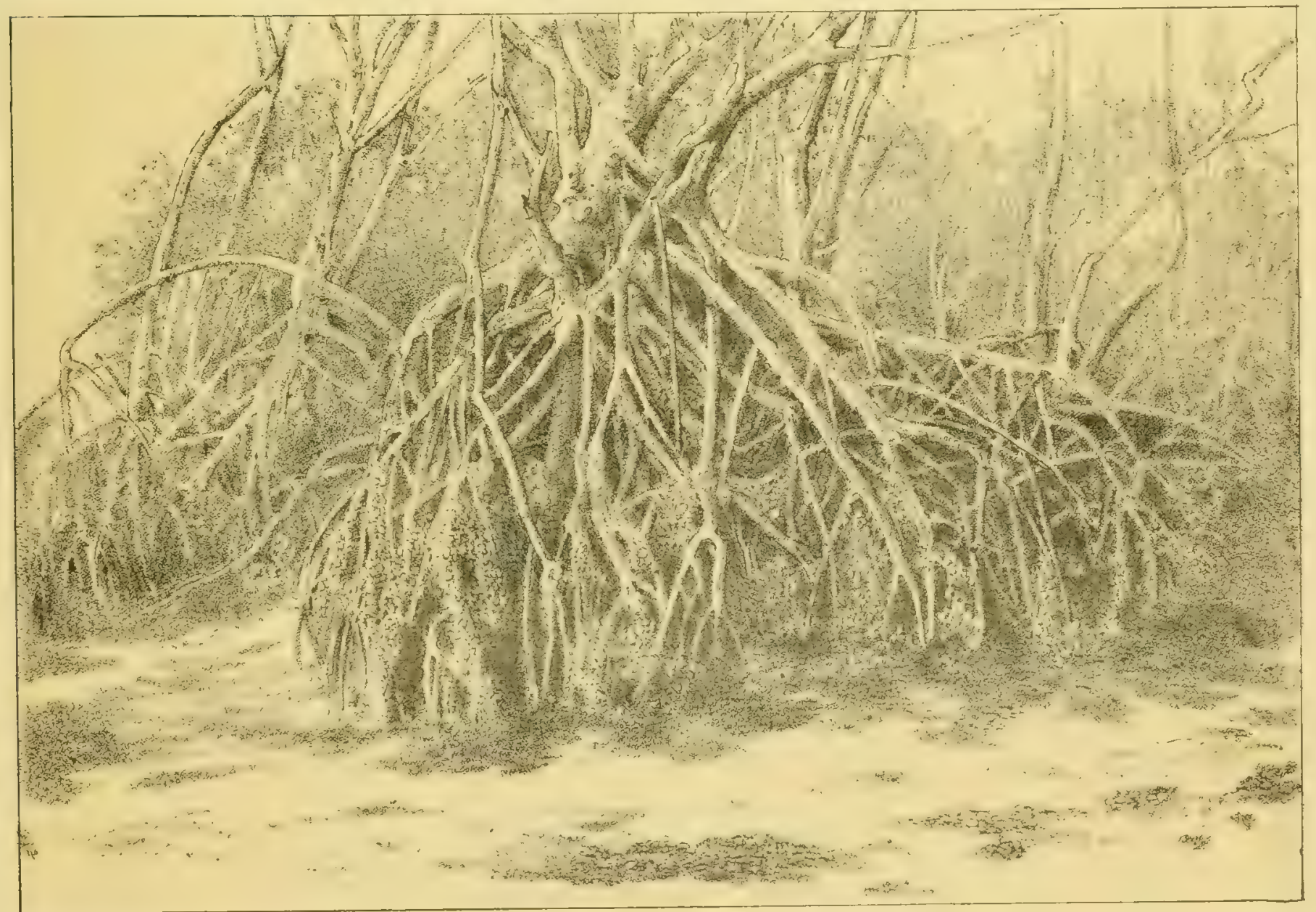





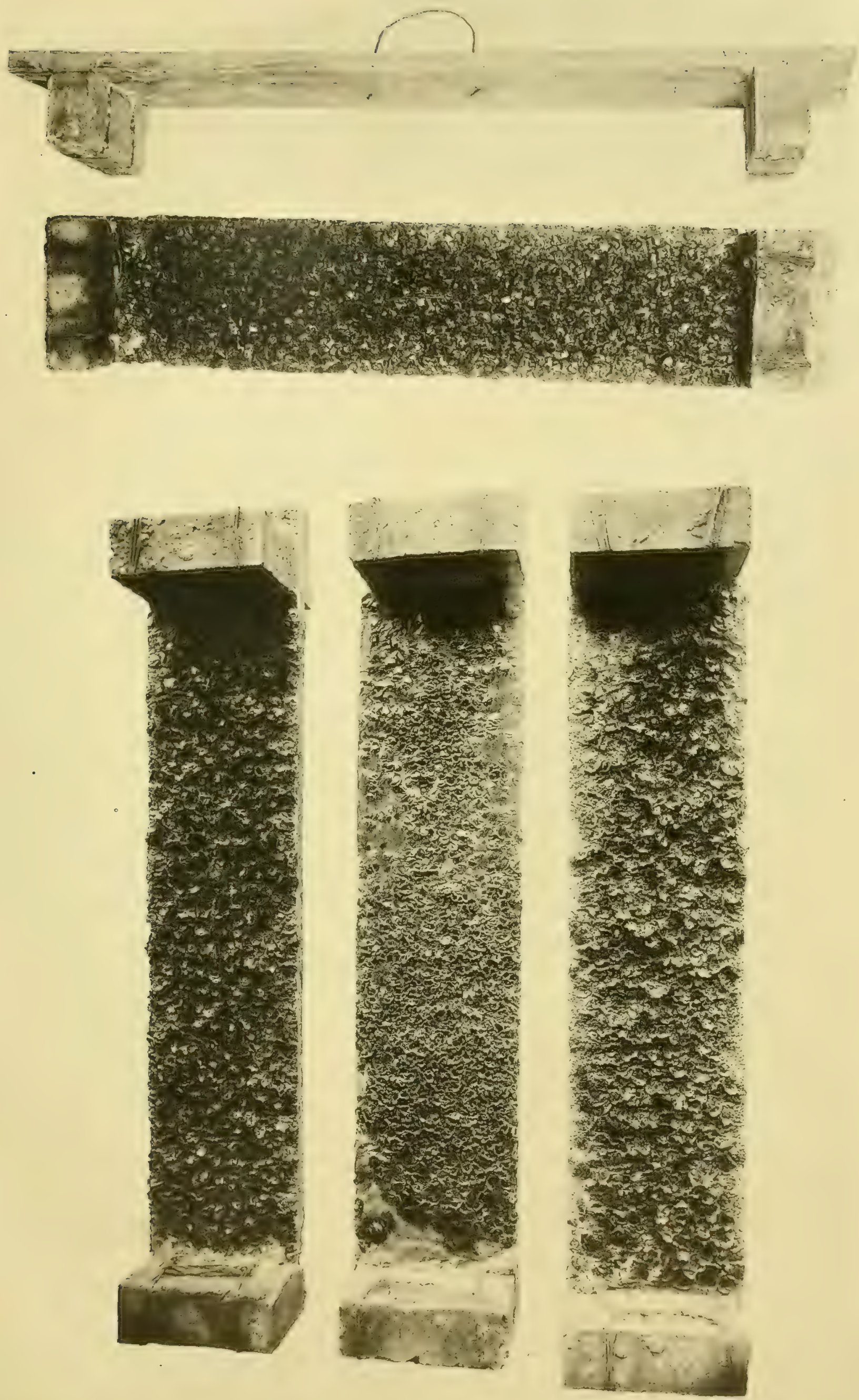

Plate IX
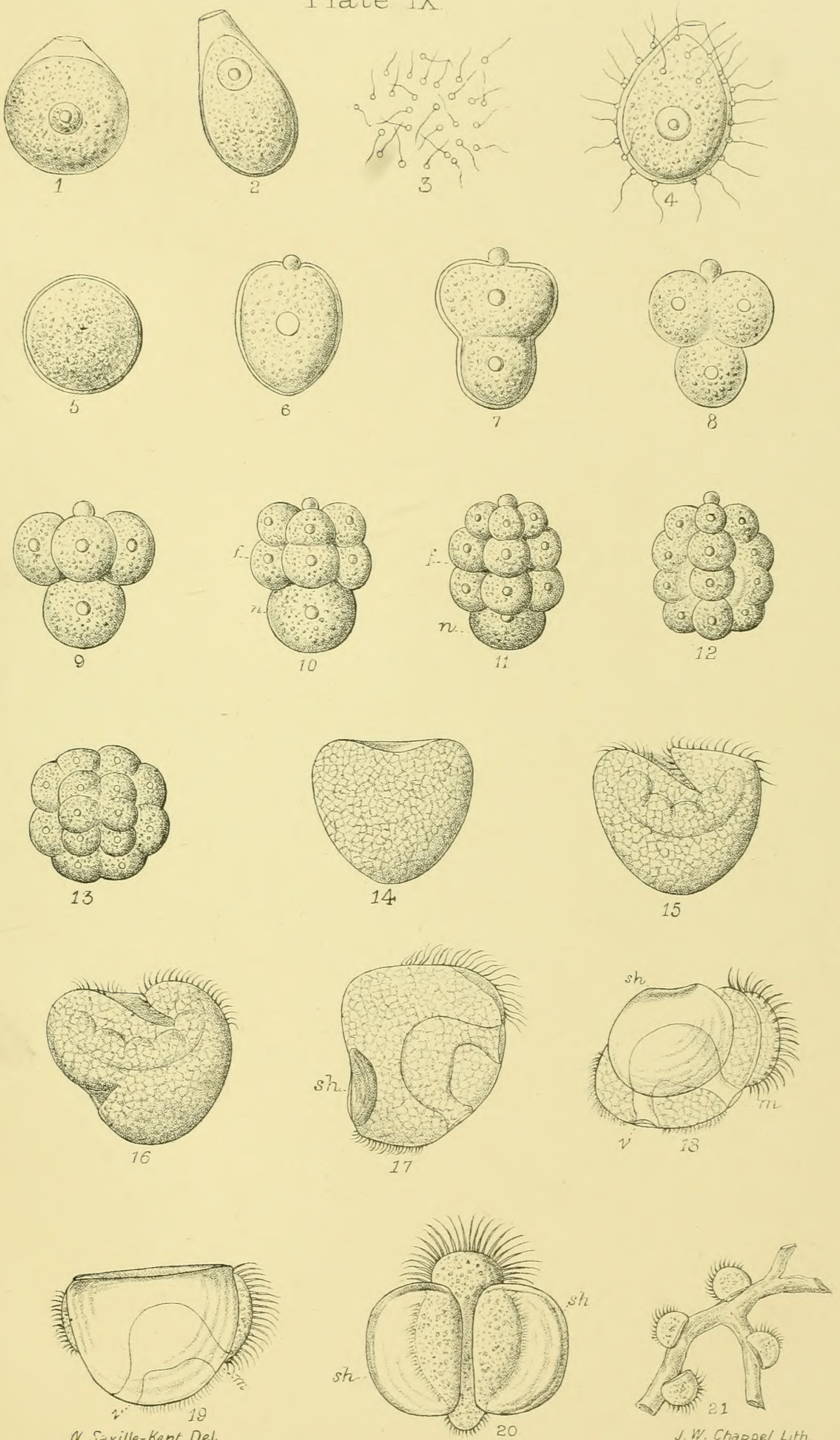

EMBryology of DStREA ClDMERATA 

